\title{
ULUSLARARASI İNSAN HAKLARI HUKUKUNUN BİR KAYNAĞI OLARAK ULUSLARARASI ÖRF VE ÂDET HUKUKU
}

\author{
Şahin Eray KIRDIM* \\ Atahan DEMIRKOL ${ }^{* *}$
}

\section{$\ddot{O} Z$}

Bu çalışmada uluslararası örf ve âdet hukuku ile uluslararası insan hakları hukuku arasındaki ilişki incelenmektedir. Uluslararası insan hakları hukuku uluslararası hukukun görece yeni bir alt dalı olup, İkinci Dünya Savaşı sonrasında ortaya çıkmıştır. Doktrinde uluslararası insan hakları hukukunun kaynaklarına ilişkin tartışmalar hâlâ devam etmektedir. Bu tartışmalardan bir tanesi de uluslararası örf ve âdet hukukunun, uluslararası insan hakları hukukuna kaynaklık edip etmediğine yöneliktir. Doktrindeki bazı yazarlar, uluslararası örf ve âdet hukuku normlarının uluslararası insan hakları hukuku kurallarının kaynă̆ı olamayacağını ileri sürseler de eldeki çalışma bunun aksini iddia etmektedir. Bu amaçla çalışma öncelikle uluslararası örf ve âdet hukuku ile uluslararası insan haklart hukukunun genel niteliklerini kısaca açıklamaktadır. Daha sonra ise bu ikisi arasındaki ilişkide, ilkinin ikincisine erga omnes nitelik kazandırarak olumlu, ancak bazı devletleri kuralların oluşum sürecinden dışlayarak olumsuz etki yaptığını ileri sürmektedir. Bu olumsuz etki özellikle Uluslararası Hukuka Üçüncü Dünya Yaklaşımları literatürü üzerinden açılanmaktadır.

Anahtar Kelimeler: Insan Haklarl, Uluslararası Insan Haklarl Hukuku, Uluslararası Örf ve Âdet Hukuku, Erga Omnes, TWAIL

\section{CUSTOMARY INTERNATIONAL LAW AS A SOURCE OF INTERNATIONAL HUMAN RIGHTS LAW}

\section{ABSTRACT}

This study examines the relationship between customary international law and international human rights law. International human rights law is a relatively

* Dr. Öğr. Üyesi, Afyon Kocatepe Üniversitesi İktisadi ve İdari Bilimler Fakültesi, Siyaset Bilimi ve Kamu Yönetimi Bölümü/AFYONKARAHİSAR, e-posta: yekirdim@aku.edu.tr ORCID: 0000-0003-4207-6559

** Arş. Gör., Afyon Kocatepe Üniversitesi İktisadi ve İdari Bilimler Fakültesi, Siyaset Bilimi ve Kamu Yönetimi Bölümü/AFYONKARAHISAR, e-posta: ademirkol@aku.edu.tr

ORCID: 0000-0002-7185-5781

DOI : 10.34246/ahbvuhfd.1018775

Yayın Kuruluna Ulaştığı Tarih $\quad$ :09/05/2021

Yayınlanmasının Uygun Görüldüğü Tarih: 27/08/2021 
new sub-branch of international law, which emerged after the Second World War. The debates in the doctrine regarding the sources of international human rights law still continue. One of these debates is about whether customary international law is a source of international human rights law. Although some authors argue that customary international law norms cannot be a source of international human rights law rules, the present study claims otherwise. For this purpose, this study briefly explains the general characteristics of customary international law and international human rights law. Later, on the relationship between these two, it is argued that the former has a positive effect on the latter by giving erga omnes character to it, but a negative effect by excluding some states from the formation of the rules. This negative effect is explained in particular through the Third World Approaches to International Law literature.

Keywords: Human Rights, International Human Rights Law, Customary International Law, Erga Omnes, TWAIL

\section{GíRiş}

İnsan hakları, birey ile devletin tarih boyunca karşı karşıya geldiği alanlardan biri olmuştur. ${ }^{1} \mathrm{Bu}$ anlamda insan hakları, liberal bireyci dünya görüşüne dayalı olarak, bireylere devletin ve toplumun ulaşamayacağ 1 bir "dokunulmaz alan" sağlamaktadır. ${ }^{2}$ Ancak belirtmek gerekir ki genellikle

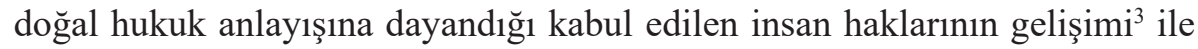
insan hakları hukukunun gelişimi birbirlerinden farklı zemin ve zamanlarda söz konusu olmuştur. Diğer taraftan insan hakları hukukunun ulusal düzeyde gelişimi ile uluslararası düzeyde gelişimi arasında da bir paralellik bulunmamaktadır. Zira aşağıda da ele alınacağı üzere insan haklarının ulusal düzeyde anayasa ve benzeri belgelerde yer alması 17 . ve 18 . yüzyıllarda mümkün olmuş iken, uluslararası insan hakları hukukunun gelişimi için 20. yüzyılın ikinci yarısı, daha somut bir ifadeyle Birleşmiş Milletler (BM) sisteminin kurulması beklenmiştir.

1 Charles Beitz, "What Human Rights Mean”, 2003, 132(1), Daedalus, s. 39.

2 Murat Barna, "Sosyal Devlet ve Eşitlik", 2001, 3, İzmir Barosu Dergisi, s. 109.

3 Jack Donnelly, "Human Rights as Natural Rights", 1982, 4(2), Human Rights Quarterly, s. 391 
1948 yılında kabul edilen İnsan Hakları Evrensel Beyannamesi ${ }^{4}$ (İHEB) ile ulusal insan hakları anlayışı, uluslararası bir boyut kazanmıştır. Böylece devletler arasındaki ilişkileri düzenleyen uluslararası hukukun bir alt dalı olarak, devletler ile bireyler arasındaki ilişkileri uluslararası seviyede düzenleyen, insan haklarını uluslararası ve ulusal düzeyde korumayı ve geliştirmeyi amaçlayan uluslararası insan hakları hukuku ortaya çıkmıştır. Uluslararası insan hakları hukukuyla birlikte artık insan haklarının evrensel düzeyde korunmasını gerektirecek mekanizmalar oluşturulması gerekliliği de hasıl olmuştur. Uluslararası insan hakları hukukunun oluşumu sürecinde ise uluslararası hukukun da bir kaynağı olan örf ve âdetin büyük etkisi vardır. Zira çoğunlukla bağlayıcı niteliği olmayan beyannameler ve sadece imzacılarını bağlayan antlaşmalar üzerinden oluşturulan uluslararası insan hakları hukuku kurallarının evrensel bir nitelik kazanmasında devletlerin genel uygulamaları ile bu uygulamaları bir hukuki gereklilik nedeniyle yapmaları sonucunda ortaya çıkan uluslararası örf ve âdet hukukunun katkısı bulunmaktadır.

Ancak uluslararası örf ve âdet hukukunun uluslararası insan hakları hukukuna olumlu mu yoksa olumsuz mu katkıda bulunduğu, tam olarak hangi açıdan kaynaklık ettiği ve bu süreçteki etkisi tartışmaya açıktır. Bu anlamda eldeki çalışma, uluslararası örf ve âdet hukuku kuralları ile uluslararası insan hakları hukuku arasındaki ilişkiyi konu edinmektedir. Tarafımızca yapılan Türkçe literatür taraması göstermiştir ki doğrudan bu ilişkiyi konu edinen bir çalışma bulunmamaktadır. Bu anlamda çalışma, bildiğimiz kadarıyla Türkçe uluslararası hukuk literatüründe ilk olma özelliğini taşımakta ve bu alandaki boşluğun doldurulmasına naçizane bir katkı sağlamayı amaçlamaktadır.

$\mathrm{Bu}$ amaca ulaşmak için çalışma üç ana bölüme ayrılmıştır. Birinci bölümde uluslararası örf ve âdet hukukunun oluşumu, kapsamı ve bağlayıc1lığ gibi hususlar çalışmanın sınırlılığı göz önünde bulundurularak doktrindeki tartışmalar üzerinden açıklanmıştır. İkinci bölümde ise insan hakları kavramı açıklandıktan sonra, ulusal ve uluslararası insan hakları hukukunun gelişimi doktrinde üzerinde en çok durulan hususlarla sınırlı olarak aktarılmıştır. Birinci ve ikinci bölüm üzerine inşa ettiğimiz üçüncü bölümde ise, insan hakları hukukunun kaynakları tartışılmıştır. Bu tartışma hem doktrindeki görüşler hem de ulusal ve uluslararası içtihat hukuku çerçevesinde ele alınmıştır. $\mathrm{Bu}$ bölümde temel olarak uluslararası yaptırım mekanizmalarına sahip olmak konusunda eksiklikleri bulunan uluslararası insan hakları hukukunun

UN General Assembly, Universal Declaration of Human Rights, 10 December 1948, 217 A (III). 
evrensellik iddiasının uluslararası örf ve âdet hukukunun kaynaklığ 1 üzerinden desteklenip desteklenmeyeceği sorusuna cevap aranmıştır. Ayrıca uluslararası insan hakları hukukuna yönelik özellikle Uluslararası Hukuka Üçüncü Dünya Yaklaşımları (Third World Approaches to International Law - TWAIL) akademisyenleri tarafından dile getirilen evrensellik eleştirisi üzerinde durulmuştur.

$\mathrm{Bu}$ bağlamda çalışmada iki temel iddia gündeme getirilmektedir. Birincisi, uluslararası örf ve âdet hukuku uluslararası insan hakları hukukuna erga omnes nitelik kazandırarak evrensel olarak uygulanabilirliğine katkıda bulunmaktadır. Ancak ikinci olarak, uluslararası insan hakları hukuku kurallarının oluşumu süreci Üçüncü Dünya devletlerini dezavantajlı bir konuma getirmektedir, zira Birinci Dünya devletleri uluslararası örf ve âdet hukuku kurallarının oluşumunda ağırlıklı bir söz hakkına sahiptir. $\mathrm{Bu}$ durum, süreçten dışlanan devletlerin evrensel olması beklenen insan haklarına yabancılaşmasına ve uygulamada sorunlar yaşanmasına yol açabilecektir.

\section{ULUSLARARASI ÖRF VE ÂDET HUKUKUNUN ANLAM, KAPSAM VE OLUŞUMU}

Kelsen, uluslararası ilişkilerde "daimî barış sorununun çözümünün ancak uluslararası hukuk çerçevesinde aranabileceğini” kabul etmektedir. ${ }^{5}$ Ancak bu kabul, uluslararası hukuka koşulsuz ve şartsız bir meşruiyet atfedilmesi ve sonsuz bir güven duyulması gerektiği anlamına gelmemektedir. Nitekim, ana akım uluslararası hukuk teorilerinden ayrılan bazı çalışmalar, disiplinin meşruluğunu sorgulayan yaklaşımlar önermişlerdir. ${ }^{6} \mathrm{Bu}$ yaklaşımlar, uluslararası hukukun güçlü devletlerin görece güçsüz devletler üzerinde bir dış politika ve baskı aracı olarak kullandığını ileri sürmektedir. ${ }^{7}$ Nitekim Byers'e göre de uluslararası hukuk, yapılışı ve kurallarının değiştirilmesi bağlamında açık şekilde güçlü ve güçsüz devletler arasında bir farklılık göstermektedir. ${ }^{8}$ Benzer bir şekilde Trimble ise uluslararası hukukun ancak bir "maskaralık (charade)" olduğunu ifade etmektedir, zira devletler ancak

5 Hans Kelsen, "Peace through Law", 1943, 2(1), Journal of Legal and Political Sociology, s. 53.

6 Şahin Eray Kırdım, "TWAIL’i Anlamak: Uluslararası Hukuka Eleştirel Bir Yaklaşım”, 2021, 41(1), Public and Private International Law Bulletin, s.129-158; Hürkan Çelebi/Ali Murat Özdemir, "Uluslararası Hukukta Eleştirel Yaklaşımlar", 2010, 7(25), Uluslararası İlişkiler Dergisi, s. 69-90.

7 Makau Mutua, "What Is TWAIL?", 2000, 94, Proceedings of the ASIL Annual Meeting, s. 31-38.

8 Michael Byers, Custom, Power and the Power of Rules: International Relations and Customary International Law, Cambridge University Press, 1999, s. 35. 
kendi çıkarlarıyla uyuştuğu takdirde uluslararası hukuka saygı duyarlar; aksi durumda önemsemezler. ${ }^{9}$

Varlığı ve neye/kime hizmet ettiği tartışmalı olan uluslararası hukuk, iki temel yolla üretilir: bilinçli ve kasıtlı bir hukuk yapma süreci sonunda ortaya çıkan antlaşmalar ile uzun bir süreç sonunda oluşan (oluşturulan değil) ve örf ve âdete dayalı kurallar. ${ }^{10}$ Uluslararası hukukun tartışmalı olduğu bir ortamda, uluslararası örf ve âdet hukukunun da sorgulamaya açılması kaçınılmazdır, ki literatürde bu sorgulamayı yapan çalışmaların sayısı giderek artmaktadır. ${ }^{11}$ İlerleyen kısımlarda oluşumu anlatılacağından bahisle söylenebilir ki uluslararası örf ve âdet hukuku da güçlü ve zayıf devletler arasındaki eşitsizliğin somut gösterge alanlarından birisidir. Bu yorum bir ön kabulden ileri geliyor gibi görünse de bunu akademik bir temele dayandırmak amacıyla, ilk olarak uluslararası örf ve âdet hukukunun tanımı, oluşumu ve bağlayıcılığı tartışılmalıdır. Bu kapsamda çalışmanın bu bölümü, anılan tartışmalara yer vererek uluslararası örf ve âdet hukukuna genel bir bakışs sunmaktadır.

\section{A. Uluslararası Örf ve Âdet Hukukunun Tanımı}

Artık neredeyse her hukuk otoritesi tarafindan kabul edildiği şekliyle uluslararası örf ve âdet hukuku, uluslararası hukukun aslî kaynaklarındandır. ${ }^{12}$ Uluslararası örf ve âdet hukuku, en basit ve genel haliyle uluslararas1 alanda bir gelenek haline gelmiş devlet davranışlarının artık hukuk normu olarak bağlayıcı nitelikte algılanmasıyla oluşan kurallar bütünü olarak tanımlanabilir. ${ }^{13}$ Uluslararası hukuka kaynaklık eden örf ve âdet hukukunun

$9 \quad$ Philip R. Trimble, “A Revisionist View of Customary International Law”, 1986, 33, UCLA Law Review, s. 665.

10 Robert Kolb, "Selected Problems in the Theory of Customary International Law", Netherlands International Law Review, 2003, 50(2), s. 120. Burada not edilmelidir ki modern uluslararası hukukun kaynakları yalnızca uluslararası antlaşmalar ile örf ve âdet hukuku ile sınırlı değildir. Bunlar asli kaynaklar olmakla beraber, uygar uluslarca kabul edilen genel hukuk ilkeleri, içtihat hukuku ve öğreti de uluslararası hukuka kaynaklık etmektedir. Bkz. Hugh Thirlway, The Sources of International Law, 2. Bask1, Oxford University Press, 2019.

11 B. S. Chimni, "Customary International Law: A Third World Perspective", 2018, 112(1), American Journal of International Law, s. 2; B. S. Chimni, "Prolegomena to a Class Approach to International Law", 2010, 21(1), , European Journal of International Law, s. 57-82; George Rodrigo Bandeira Galindo/César Yip, "Customary International Law and the Third World: Do Not Step on the Grass", 2017, 16(2), Chinese Journal of International Law, s. 251-270.

12 A. Füsun Arsava, "Uluslararası Hukukta Güç ve Hukuk İlişkisi”, 2012, 3(10), TAAD, s. 367.

13 Jack L. Goldsmith/Eric A. Posner, “A Theory of Customary International Law”, 1999, 66(4), The University of Chicago Law Review, s. 1116. 
bu niteliğe sahip olduğu ise -diğer pek çok kaynak yanında- Uluslararası Adalet Divanı (UAD) Statüsü' nün 38/1 hükmünden anlaşılmaktadır. ${ }^{14} \mathrm{Bu}$ hükme göre, "hukuk olarak kabul edilmiş genel bir uygulamanın kanıtı olarak uluslararası yapılagelmiş kurallar", uluslararası hukukun kaynăğdır. Benzer bir tanımlama, Restatement (Third) of Foreign Relations Law of the United States tarafından da yapılmıştır. Bu tanımda da uluslararası örf ve âdet hukuku "bir hukuki zorunluluk duygusundan gelen, devletlerin genel ve sürekli bir uygulamasından kaynaklanan" hukuk normu olarak ifade edilmiştir. ${ }^{15}$

Genel kabule göre, uluslararası örf ve âdet hukuku kurallarının üretilmesi sürecinde devletlerin kurala ilişkin açık ve karşılıklı bir kabulü olmasa ve formel bir süreç yürütmeseler dahi bağlayıcı hukuk kuralları ortaya çıkabilir. ${ }^{16}$ Diğer bir görüşe göre ise devletler geleneksel hukuk kuralı yaratma yöntemleri haricinde de hukuk kuralı üretebilirler. Örneğin Henkin, geleneksel uluslararas1 örf ve âdet hukukunu tanımlayarak bir ayrıma gitmektedir. Ona göre bu kapsamdaki hukuk normları, "üretilmemiş" ancak "sonuç olarak" karşımıza gelmiştir. Bir başka ifadeyle, tarihsel süreçte geleneksel uluslararası örf ve âdet hukuku normları hep bir yerlerde var olmuşlardır. Dolayısıyla bunlar, bazen bir anayasal hüküm içerisinde, bazen de orta çağlarda olduğu gibi genel hukuk anlayışında yer almaktadırlar. Temel fark olarak, bu kurallar yerli yerinde durmaktadır, bir diğer ifadeyle devletlerin bu pratiği geliştirmeleri söz konusu değildir. Ancak devletler bu hukuk kurallarını tanıma yoluna gitmişlerdir. İkinci yöntemde ise (ki Henkin buna "non-conventional law" demektedir) bu kurallar bizatihi kasıtl1, isteyerek ve bir saik güderek devletler tarafından oluşturulmaktadır. ${ }^{17}$

Her ne kadar bir dönem uluslararası hukuk demek örf ve âdet hukuku demek olsa da ${ }^{18}$ uluslararası örf ve âdet hukuku, varlığına dair fikrin ortaya atılmasından itibaren dönem dönem tartışmalara konu olmuştur. ${ }^{19}$ Hatta

14 Statute of the International Court of Justice, 26 June 1945, 59 Stat. 1055, 33 U.N.T.S. 933.

15 Restatement of the Law, Third, Foreign Relations Law of the United States, American Law Institute, 1987, Section 102.

16 J. Patrick Kelly, "The Twilight of Customary International Law", 1999, 40, Virginia Journal of International Law, s. 460.

17 Louis Henkin, "Human Rights and State Sovereignty", 1996, 25, Georgia Journal of International and Comparative Law, s. 37.

18 Henkin, s. 35.

19 David P. Fidler, "Challenging the Classical Concept of Custom: Perspectives on the Future of Customary International Law”, 1996, 39, German Yearbook of International Law, s. 198. 
Kunz tarafindan örf ve âdet hukuku doğası gereği sorunlu görülmüştür. ${ }^{20}$ Bunun nedenleri arasında sayılabileceklerin belki de en önemlisi uluslararası örf ve âdet hukukunun oluşumunda tüm devletler arasında görüş birliği sağlanmasına nadiren gereklilik duyulmasıdır. ${ }^{21}$ Dahası Kelly, uluslararası örf ve âdet hukukunun uluslararası hukukun bir kaynağı olarak gösterilmesinden vazgeçilmesini, bunun yerine karşılıklı mutabakatlara dayalı hukuk üretme sisteminin getirilmesi gerektiğini tartışmıştır. ${ }^{22}$

Ancak genel kanıya göre uluslararası örf ve âdet hukuku uluslararas1 ilişkiler alanını bir anlamda sarmış ve bu disiplinin her tarafına yayılmıştır çünkü hem hükümetler -bir nedenden ötürü- bu normlara uymaya gayret etmekte, hem de ulusal mahkemeler kararlarını verirken bunları dikkate almaktadırlar. ${ }^{23}$ Özellikle 20. yüzyılın ikinci yarısından itibaren, BM'nin uluslararası ilişkiler ve hukuk sistemini sözde daha katılıme bir yapıya dönüştürmesiyle uluslararası hukukun kaynakları arasında uluslararası çok taraflı antlaşmalar ağırlık kazanmaya başlamıştır, ancak belirtilmelidir ki bu antlaşma hukuku çoğunlukla örf ve âdetin antlaşmalara dönüştürülmesiyle oluşmuştur. Bunun da en büyük kaynağı, BM altında yapılanmış olan Uluslararası Hukuk Komisyonu (International Law Comission) aracılı̆̆ıyla yürütülen "kodifikasyon ve geliştirme" programıdır. Bu program kapsamında örf ve âdetler, uluslararası çok taraflı antlaşmalara evrilmiştir. ${ }^{24}$

\section{B. Uluslararası Örf ve Âdet Hukukunun Oluşumu}

Daha önce olmayan bir kuralın inşası veya mevcut bir kuralın ihlâli sonucunda ortaya çıkabilen uluslararası örf ve âdet hukuku, bir güç hukuku olarak nitelendirilebilir. ${ }^{25}$ Arsava'nın açık ifadesine göre de uluslararası örf ve âdet hukukunun oluşumu "özellikle önemli ve güçlü devletlerin tutumuna bağlıdır" ve hatta "bir devlet ne kadar güçlü ise, uluslararası örf ve âdet hukukunu o ölçüde şekillendirebilir." ${ }^{26}$ Benzer şekilde Goldsmith ve Posner

\footnotetext{
20 Josef L. Kunz, "The Nature of Customary International Law", 1953, 47(4), American Journal of International Law, s. 663.

21 Francisco Orrego Vicuña, "Costumary International Law in a Global Community: Tailor Made?", 2005, 38(148), Estudios Internacionales, s. 25.

22 Kelly, The Twilight of Customary International Law.

23 Goldsmith/Posner, A Theory of Customary International Law, s. 1113.

24 Henkin, Human Rights and State Sovereignty, s. 35, 36.

25 Arsava, Uluslararası Hukukta Güç ve Hukuk İlişkisi, s. 367.

26 Arsava, s. 367.
} 
da uluslararası örf ve âdet hukukunu güçlü devletlerin lehine olan bir hukuk kaynağ 1 olarak ifade etmişlerdir. ${ }^{27} \mathrm{Bu}$ durum şüphesiz ki uluslararası örf ve âdet hukukunun oluşum sürecinden ileri gelmektedir. Zira Joyner'e göre uluslararası örf ve âdet hukukunun ortaya çıkış süreci çok da karmaşık bir yapıdan oluşmamaktadır: eğer ki devletlerin -genellikle de güçlü devletlerin1srarlı bir şekilde uygulamaya devam ettikleri ve uzun süredir uygulamada olan belirli bir yöndeki davranış mevcutsa ve bu davranışın uygulanmasının bir hukuki zorunluluktan ileri geldiğine inanılıyorsa, bir başka deyişle bu uygulamanın hukuki bir kurala dönüştügü kanısı oluşmuşsa, burada bir uluslararası örf ve âdet hukuku normunun varlığından bahsetmek mümkün olacaktır. $^{28}$

$\mathrm{Bu}$ sürece genel bir bakış sonucunda görülecektir ki uluslararası örf ve âdet hukukunun oluşumunda iki temel unsur bulunmaktadır: genel devlet uygulamaları ve opinio juris. ${ }^{29} \mathrm{Bu}$ unsurlardan ilki, nesnel ölçüt (veya maddi öğe) olarak sınıflandırılmaktayken, ikincisi ise öznel ölçüt (veya manevi/ psikolojik öğe) olarak adlandırılmaktadır. ${ }^{30}$ Genel uygulama, davranışın ısrarlı bir şekilde ve uzun sayılabilecek bir süre boyunca uygulanmasını ifade eder. Opinio juris ise, söz konusu davranışı bir örf ve âdet hukuku normu olarak kabul etmeyi, bir başka ifadeyle genel devlet uygulamalarına hukuken bağlıymış inanciyla hareket edilmesini ifade etmektedir. ${ }^{31}$ UAD'nin hem 1969 tarihli North Sea Continental Shelf hem de 1986 tarihli Nicaragua kararlarında uluslararası örf ve âdet hukukunun oluşması için "yerleşmiş bir uygulama" ve "opinio juris" olması gerektiği vurgulanmıştır.

Genel uygulama, yani maddi gerçeklik yaygın, 1srarlı ve net bir devlet uygulamasını ifade etmektedir ve uluslararası örf ve âdet hukukunun

27 Goldsmith/Posner, A Theory of Customary International Law, s. 1114.

28 Daniel H. Joyner, "Why I Stopped Believing in Customary International Law”, 2018, 9(1), Asian Journal of International Law, s. 3.

29 Chimni, Customary International Law, s. 2.

30 Andrew Guzman, "Saving Customary International Law”, 2005, 27(1), Michigan Journal of International Law, s. 123.

31 Byers, s. 151.

32 North Sea Continental Shelf cases (Federal Republic of Germany v Netherlands, Federal Republic of Germany v Denmark), merits, 1969 ICJ Rep. 3, para. 77; Military and Paramilitary Activities in and against Nicaragua (Nicaragua v United States of America), merits, 1986 ICJ Rep. 14, para. 207. 
oluşumundaki gerekliliği çok da tartışmalı değildir. ${ }^{33}$ Ancak genel uygulamanın ne zaman ve hangi şartlar altında oluşacağına dair soru işaretlerinin de giderilmesi gerekmektedir. Doktrinde çeşitli görüşler bulunan bu konu hakkında Kunz, genel uygulamanın unsurlarını tanımlarken âdet, devamlılık ve kesintisizlik öğelerine yer vermektedir. ${ }^{34} \mathrm{Bu}$ bağlamda bir uygulamanın uluslararası örf ve âdet hukuku normuna dönüşebilmesi için öncelikle "tüm ülkeler tarafindan değil" ancak "genel bir kesim tarafından" kesintisiz, 1srarlı ve tekrar eden bir şekilde uygulanıyor/uygulanmış olması gerekmektedir. Nicaragua davasında da UAD, ilgili örf ve âdet hukuku normunun ortaya çıkması için bütün devletlerin "mutlak katı bir uyum içinde" olması gerekmediğini, ancak genel devlet uygulamalarının kuralı olumlayıcı yönde olmasının yeterli olduğuna hükmetmiştir. ${ }^{35}$ Dolayısıyla, bütün devletlerin bu kural hususunda rızas1 aranmamaktadır. ${ }^{36} \mathrm{Bu}$ durumda, hangi devlet davranışlarının genel uygulamayı oluşturacağını da belirlemek gerekebilir. $\mathrm{Bu}$ hususa ilişkin olarak Müllerson, protestoları, ulusal yargı kararlarını, resmî açıklamaları ve benzeri fiilleri genel uygulamanın örnekleri olarak ifade etmektedir. ${ }^{37}$ Scharf ise genel devlet uygulamasının yasama, yürütme veya yarg1 erkinin kapsamına giren uygulamalarla ortaya çıkabileceği görüşünü ortaya koymaktadir. ${ }^{38}$

Opinio juris, her ne kadar Kunz tarafindan genel uygulama ilkesiyle eşit önemde görülse de ${ }^{39}$ Goldsmith ve Posner'a göre uluslararası örf ve âdet hukukunun asıl ilkesidir. ${ }^{40}$ Genel uygulama ilkesinin aksine opinio juris doktrinde tartışmalı bir konudur ${ }^{41}$ ve doktrinde bu konuda temel olarak iki görüş bulunmaktadır: ortaklıkçı/gönüllü (voluntarist/consensual) yaklaşım ile

33 Goldsmith/Posner, "A Theory of Customary International Law", s. 1116; Maurice Mendelson, "The Subjective Element in Customary International Law", 1996, 66(1), British Yearbook of International Law, s. 177.

34 Kunz, The Nature of Customary International Law, s. 666.

35 Military and Paramilitary Activities in and against Nicaragua, para. 186.

36 Hüseyin Pazarc1, Uluslararası Hukuk, 16. Bask1, Turhan Kitabevi, 2017, s. 100.

37 Rein Müllerson, "On the Nature and Scope of Customary International Law", 1997, 2(1), Austrian Review of International and European Law Online, s. 342.

38 Michael P. Scharf, “Accelerated Formation of Customary International Law”, 2014, 20, ILSA Journal of International and Comparative Law, s. 312.

39 Kunz, The Nature of Customary International Law, s. 665.

40 Goldsmith/Posner, A Theory of Customary International Law, s. 1116.

${ }^{41}$ Christian Dahlman, "The Function of Opinio Juris in Customary International Law", 2012, 81(3), Nordic Journal of International Law, s. 327. 
entelektüel (intellectualist) yaklaşım. İlk grup, riza ve opinio juris'i neredeyse eş anlamlı görmekteyken, ikinci grup rıza ve hukuk olarak kabul etmenin ayrı kavramlar olduğunu iddia etmektedir. ${ }^{42}$ D'Amato, ikinci gruba dahil olarak rıza ve opinio juris' in aynı manada olmadığını ileri sürmektedir. Bu görüşünü savunurken D'Amato, güçlü ve güçsüz devletlerin bir arada bulunduğu bir toplulukta, güçsüz olanların rızalarının güçlü devletlerin isteğinden bağımsız olamayabileceğini tartışmaktadır. ${ }^{43}$

Ancak belirtilmelidir ki opinio juris, uluslararası örf ve âdet hukukuna ilişkin bir normun varlığını iddia etme hususunda uygulamada zorluklar çıkartmaktadır. Öyle ki, örf ve âdet hukuku normunun varlığını iddia eden tarafın, karşı tarafın bu normu kabul ettiğini ve dolayısıyla da bu norma rıza göstermiş olduğunu kanıtlaması gerekmektedir. ${ }^{44}$ Tahmin edileceği üzere bu gereklilik oldukça tartışmalı bir alan yaratmaktadır, ki bu tartışma uluslararası örf ve âdet hukukunun oluşumunda açık rızanın gerekliliği üzerinde yoğunlaşmaktadır. Bu bağlamda, bir örf ve âdet hukuku kuralını kabul ettiğini açıkça beyan etmeyen devletler açısından bu kural oluşmuş sayılacak mıdır? $\mathrm{Bu}$ sorunun cevabı bir sonraki bölümde detaylı olarak ele alınıyor olsa da burada kısaca belirtilmelidir ki uluslararası örf ve âdet hukukunda kural olarak sükût ikrardan gelmektedir. Bu vecize benzer bir şekilde Mendelson da devletlerin açıkça rıza beyanında bulunmasalar bile örtülü bir rıza beyanıyla bu normları kabul ettiklerini ve dolayısıyla bu kurallarla bağlı olduklarını ifade etmektedir. ${ }^{45}$

Cevaplanması gereken bir soru da uluslararası örf ve âdet hukukunun gerçekten nasıl oluştuğuna, bir başka ifadeyle hangi otorite tarafından bunların dört başı mamur birer hukuk normu olarak ilân edileceğine ilişkindir. Bir örf ve âdetin genel devlet uygulamasına sahip olduğuna ve devletlerin bu uygulamayı yaparken mevzu bahis örf ve âdeti bir hukuk kuralıymışçasına addederek yaptığına kim karar verecektir? Bu sorunun yanıtı bir görüşe göre hiç kimsedir. Doktrindeki bu hâkim görüşe göre uluslararası örf ve âdet hukuku sui generis bir hukuk alanıdır, bir başka ifadeyle hukuk normu olarak ilân edilmeye ihtiyaç duymaz zira bizatihi kendisi hukukun kaynağıdır. Herhangi bir mahkemenin

42 Olufemi Elias, "The Nature of the Subjective Element in Customary International Law", 1995, 44(3), The International and Comparative Law Quarterly, s. 501.

43 Anthony A. D'Amato, The Concept of Custom in International Law, Cornell University Press, 1971, s. 68-70.

44 Pazarc1, Uluslararası Hukuk, s. 99.

45 Mendelson, The Subjective Element in Customary International Law, s. 178. 
bu kuralı uygulamasına ihtiyacı yoktur. Hukuk kuralı olmasının sebebi onu bir mahkemenin uygulamış olması değildir. Tam tersine hukuk kuralı olduğu için mahkemeler tarafindan uygulanmaktadır. ${ }^{46}$ Doktrindeki diğer görüş ise ilk görüş ile doğrudan çelişmektedir. Örneğin Austin'e göre, uluslararası örf ve âdet hukukunun oluşumu için bir egemen devlet tarafindan uygulanması veya yarg1 kararlarına girmesi gerekmektedir. ${ }^{47}$ Ancak yine de genel görüş açısından uluslararası örf ve âdet hukuku normlarını ilân eden olmasa da tanımlayan en bilinen üç otorite vardır: uluslararası mahkemeler, Uluslararası Hukuk Komisyonu ve akademisyenler. ${ }^{48}$

\section{Uluslararası Örf ve Âdet Hukukunun Bağlayıcılığı}

Uluslararası örf ve âdet hukukunun bağlayıcıllığ da en az ortaya çıkış1 kadar tartışmalı bir konudur. Bir hukuk normu haline geldiği kabul edilen örf ve âdetin kimleri ne ölçüde bağlayacağı, bu örf ve âdete ne zaman ve hangi şartlarda itiraz edileceği ve itirazın hukuki değeri doktrinde farklı görüşlerle ifade edilmektedir.

Genel görüşe göre, uluslararası örf ve âdet hukuku kural olarak açıkça rıza göstersin göstermesin tüm devletler için bağlayıcı olsa da bu bağlayıcılığı etkileyen bir konu mevzu bahis kuralın bölgesel mi genel mi olduğuna ilişkindir. ${ }^{49}$ Bazı örf ve âdet hukuku normları genel normlar olup tüm devletleri bağlarken, bazı normlar bölgesel veya yerel (spesifik bir coğrafyada yer alan devletler arasında) olabilmektedir. ${ }^{50}$ Hem doktrindeki hâkim görüş hem de uluslararası mahkeme içtihatlarına göre, ortaya çıkmış olduğu kabul edilen genel nitelikli uluslararası örf ve âdet hukuku kuralları, bu kurallara açıç̧a rıza göstersin veya göstermesin, -veya hemen aşağıda ele alınacağı üzere açıkça itiraz etmeyen- tüm devletler açısından bağlayıcı olacaktır. ${ }^{11}$ Diğer

46 Dahlman, The Function of Opinio Juris in Customary International Law, s. 328.

47 John Austin, Lectures on Jurisprudence, J. Murray, 1869; Dahlman, The Function of Opinio Juris in Customary International Law, s. 329.

48 Joyner, Why I Stopped Believing in Customary International Law.

49 Brian D. Lepard, "Introduction", in Brian D. Lepard (ed.) Reexamining Customary International Law, Cambridge University Press, 2017, s. 10.

50 Scharf, s. 311.

51 Patrick Dumberry, "Incoherent and Ineffective: The Concept of Persistent Objector Revisited", 2010, 59(3), International and Comparative Law Quarterly, s. 780 ("Uluslararas1 teamül hukukunda halihazırda kristalize olmuş bir kural, uluslararası topluluğun tüm devletleri için bağlayıcıdır); Restatement (Third) of the Foreign Relations Law of the United States § 102(2) (1987) ("Uluslararası teamül hukuku tüm devletler için bağlayıcıdır.); 
taraftan bölgesel veya yerel nitelikli örf ve âdet kurallarının bağlayıcıllğı, ilgili devletlerin açık rızasına bağlıdır. ${ }^{52} \mathrm{Bu}$ durum Shaw tarafindan bölgesel ve yerel hukuk geleneklerine saygı olarak gerekçelendirilmektedir. ${ }^{53} \mathrm{Bu}$ anlamda evrensel nitelikli örf ve âdet hukukunun devletlerin genel çoğunluğunun uygulaması veya kabulüne dayanması yeterliyken, bölgesel/yerel örf ve âdet hukukunun bütün tarafların açıkça kabulüne dayanması gereklidir. ${ }^{54} \mathrm{Bu}$ yönüyle bölgesel/yerel örf ve âdet hukukunun bağlayıcılığı konusunda daha açık bir gerekçe ve zemin oluşması gerektiği ileri sürülebilir. Bu itibarla, genel nitelikli örf ve âdet hukukunda sükût ikrardan gelmekte iken, bölgesel örf ve âdet hukukunda sükût, ret anlamına gelmektedir.

Genel nitelikli örf ve âdet hukuku kurallarının bağlayıcılığı konusunda üzerinde durulması gereken ve yukarıda ifade edilen bağlayıcılık açısından istisnai bir durum teşkil eden bir konu da literatürde "1srarlı itirazcı (persistent objector) kuralı" olarak ifade edilen müessesedir. Stein'a göre uluslararası ihtilaflarda önemli bir rol oynayacağı ön görülen bu kural açısından, ${ }^{55}$ bir uluslararası örf ve âdet hukuku normuna oluşma aşamasında itirazeı olan ve bu itirazını 1srarlı ve tutarlı bir şekilde sürdüren bir devlet, zımni kabulün bir parçası sayılamaz ve dolayısıyla da bu normla bağlı olduğu kabul edilemez. ${ }^{56}$ Ancak burada açık olan durum şudur ki, 1srarlı itirazcı kuralının uygulanabilmesi için yapılan itirazın örf ve âdet hukuku normunun oluşma aşamasındayken, bir diğer ifadeyle henüz hukuk normu olarak kabul edilmemişken yapılmış olması gerekmektedir. ${ }^{57}$ Daha açık bir şekilde, uluslararası örf ve âdet hukukunda "sonradan itiraz" (subsequent objection)

Domingues v United States, merits, 2002 IACHR, Report No. 62/02, Case 12.285, para. 48; Inter-Science Research and Development Services (Pty) Ltd v Republica Popular Moçambique, per Margo J., 19802 SA 111 T, 125 ("Bir gelenek, uluslararası hukukun genel bir kuralı haline gelirse, buna karşı çıkmayan tüm Devletleri bağlar"); Domingues v United States, merits, 2002 IACHR, Report No. 62/02, Case 12.285, para. 48.

52 David J. Bederman, "Acquiescence, Objection and the Death of Customary International Law", 2010, 21(1), Duke Journal of Comparative \& International Law, s. 32; Anthony A. D'Amato, "The Concept of Special Custom in International Law", 1969, 63(2), American Journal of International Law, s. 216.

53 Malcolm N Shaw, Uluslararası Hukuk, Çev. İbrahim Kaya vd., TÜBA, 2018, s. 65.

54 Shaw, s. 66.

55 Ted L. Stein, "The Approach of the Different Drummer: The Principle of the Persistent Objector in International Law", 1985, 26, Harvard International Law Journal, s. 457.

56 Scharf, s. 317.

57 Joel P. Trachtman, "Persistent Objectors, Cooperation, and the Utility of Customary International Law", 2010, 21, Duke Journal of Comparative \& International Law, s. 221. 
usulü bulunmamaktadır. ${ }^{58}$ Dolayısıyla 1srarlı itiraz kuralının iki belirleyicisi bulunmaktadır: örf ve âdet hukuku normunun "oluşum aşamasında" yapılan itiraz ve bu itirazın 1 srarlı ve tutarlı bir şekilde ortaya konulması. ${ }^{59}$

Bu yönüyle 1srarlı itirazcı bir devlet, örf ve âdet hukukunun bizatihi varlığına değil, bu kuralın kendisi açısından bağlayıcılığına karşı çıkmaktadır. Dolayisıyla genel devlet uygulamasindan ayrilan ve bu uygulamanın kendisi açısından bağlayıcılığını kabul etmeyen bir devletin, bu örf ve âdet hukukuyla bağlı olması da mümkün değildir. Ancak doktrinde 1srarlı itirazcı kuralının varlığı konusunun tartışmalı olduğu da ifade edilmelidir. ${ }^{60}$ Bizim de katıldığımız hâkim görüş, uluslararası örf ve âdet hukukuna 1srarlı itirazcı olarak karşı çıkan bir devletin, bu kuralla bağlı olmaktan kurtulacağ1 yönündedir. ${ }^{61}$ Ancak bununla çelişen bir şekilde, bir devletin ısrarlı itirazına rağmen bir örf ve âdet hukukuyla bağlı olup olmayacağı sorusuna da doktrinde olumlu cevaplar bulunmaktadır. ${ }^{62}$

Uluslararası örf ve âdet hukukunun bağlayıc1lığı konusunda en tartışmalı konulardan birisi de yeni devletlerin bu normlarla bağlı olup olmayacağıdır. Hâkim görüşe göre uluslararası örf ve âdet hukuku kuralları, kuralın ortaya çıkmasından sonra devletlik statüsü kazanan yeni devletler açısından da bağlayıcıdır. ${ }^{63}$ Henkin'e göre de yeni ve eski tüm devletler bu kurallarla bağlıdır. ${ }^{64}$ Ayrıca Uluslararası Hukuk Derneği'ne (International Law Association) göre, bir devletin uluslararası örf ve âdet hukukunun oluşumundan sonra kurulmuş olması, ona 1srarlı itirazc1 olma hakk1 vermez. ${ }^{65}$

58 Committee on Formation of Customary (General) International Law, Final Report of the Committee, "Statement of Principles Applicable to the Formation of General Customary International Law", International Law Association, section 15, 2000, <http://www.law. umich.edu/facultyhome/drwcasebook/Documents/ Documents/ILA\%20Report\%20on\%20 Formation\%20of\%20Customary\%20International\%20Law.pdf $>$ Erişim Tarihi 12.11.2020.

59 J. Brock McClane, "How Late in the Emergence of a Norm of Customary International Law May a Persistent Objector Object", 1989, 13, ILSA Journal of International Law, s. 20.

60 Elias, The Nature of the Subjective Element in Customary International Law, s. 39.

${ }_{61}$ Ian Brownlie, Principles of Public International Law, Clarendon Press, 1973; Michael Akehurst, "Custom as a Source of International Law", 1976, 47(1), British Yearbook of International Law, s. 1-53.

62 Maarten Bos, A Methodology of International Law, North-Holland, 1984; Hans Kelsen, Principles of International Law, 2. Bask1, Holt, Rinehart and Winston, 1966.

63 Scharf, s. 309.

64 Henkin, Human Rights and State Sovereignty, s. 36.

65 Committee on Formation of Customary (General) International Law, Section 18, s. 28. 
Her ne kadar doktrinsel bir tartışma bulunsa da ${ }^{66}$ özetle uluslararası örf ve âdet hukukunun bağlayıcıllğı kural olarak tüm devletleri kapsamaktadır. ${ }^{67}$ Devletler, yeni veya önceden kurulmuş olduğuna bakılmaksızın bu kuralla bağlı olacaklardır. Bu durumun dayanağ 1 örtülü rıza anlayışıdır. ${ }^{68}$ Örtülü rızaya karşı ileri sürülebilecek tek iddia ise, bahsedildiği üzere 1srarlı itiraz kuralında karşımıza çıkmaktadır. Israrlı itiraz ise, süresi ve yapılış biçimi açıkça belirlenmiş şekilde bir uluslararası örf ve âdet, hukuk normu haline gelmeden önce yapılan itirazı kapsamaktadır ve bu yönüyle bir uluslararası örf ve âdet hukukunun oluşumundan sonra kurulmuş devletleri kapsamamaktadır. ${ }^{69}$

\section{ULUSLARARASI İNSAN HAKLARI HUKUKUNA GENEL BİR BAKIŞ}

Bu bölümde uluslararası insan hakları hukukunun ortaya çıkış süreci ve gelişimi incelenmektedir. Ancak bu sürecin ortaya konulması için, öncelikli olarak insan haklarının ortaya çıkışına ve genel prensiplerine değinilmesi elzemdir. Burada önemle belirtilmelidir ki insan haklarının gelişimi, insan hakları hukukunun ulusal düzeyde ortaya çıkışı ve uluslararası insan hakları hukukun oluşumu, birbirlerinden farklı zemin ve zamanlarda söz konusu olmuştur. Bu itibarla örneğin Antik Yunan'da veya Çin'de insan haklarının öncü görünümleri söz konusu olsa da bunlar anlam ve kapsam bakımından modern zamanlardan oldukça farklı oldukları gibi, herhangi bir şekilde uluslararası hukukun konusu da olmamışlardır. Dolayısıyla, insan hakları ile (ulusal ve uluslararası) insan hakları hukukunun birbirlerine paralel süreçlerde ortaya çıktıkları düşünülmemelidir. Bu amaçla çalışmanın bu başlığında öncelikle insan haklarının tanımı ve gelişimine değindikten sonra, insan hakları hukukunun önce ulusal sonra da uluslararası düzeyde ortaya çıkışı ve temel birkaç insan hakları belgesine değinilmiştir.

\section{A. İnsan Hakları Kavramı ve Tarihsel Gelişimi}

Doktrin incelendiğinde görülecektir ki insan haklarının bir tanımının yapılmasında uzlaşılmış bir ölçüt yoktur. Ancak yine de kavramın genel anlamda kabul edildiği şekliyle bazı tanımlama çabalarında bulunulmuş ve

\footnotetext{
${ }^{66}$ Israrl1 itirazcılık konusundaki eleştiriler için bkz. Dumberry, s. 784.

67 Dumberry, s. 779.

68 Committee on Formation of Customary (General) International Law, Section 18, Commentary (c), s. 39.

69 Dumberry, s. 784.
} 
bunlardan bazıları üzerinde de kısmen genel bir uzlaşıya varılmıştır. Bu kısmi uzlaşma çerçevesinde insan hakları, en az düzeyde sınırlanmış ve özgür bir yaşam, hukuk önünde eşit muamele gibi haklar ile temel sosyal, ekonomik ve kültürel ihtiyaçların karşılanmasına yönelik hakları ifade etmektedir. ${ }^{70} \mathrm{Bu}$ itibarla insan hakları, Erdoğan'a göre, modern ve politik bir kavram olarak karşımıza çıkmaktadır. ${ }^{71} \mathrm{Bu}$ yönüyle insan hakları, modern insanın siyasi olarak devletten bir talebi sonucunda ortaya çıkan veya devletle arasındaki ilişkilerin sınırını çizen, insanların sadece insan olmak hasebiyle ve doğuştan sahip olduğu temel ve eşitlikçi haklardır. Bu bağlamda özetle modern anlamda insan hakları, insanları yönetenlerin zulmünden korumak amacını taşımaktadır. ${ }^{72}$

Ancak insan haklarının bu modern yönü, onun tarihsel gelişimini ve ortaya çıkış aşamalarını göz ardı etmemize sebep olamaz. Gözler'e göre insan haklarının ortaya çıkışı eski çağa, özellikle de Stoacılar'a kadar uzanmaktadır. Bu fikir, Stoacılar'da eşitlik ve kardeşlik düşüncelerine atıfta bulunulmasından kaynaklanmaktadır. ${ }^{73}$ Benzer şekilde Aybay, insan hakları kavramının ortaya çıkışı olarak adlandıracağımız sıfır noktasında birçok farklı tarih alınabileceğini ifade ederken, kendi bakış açısıyla Pers İmparatoru Büyük Kirus'un milattan önce 6. yüzyılda angaryayı ve köleliği yasaklamasını insan haklarının öncül örneklerinden birisi olarak sunmaktadır. ${ }^{74}$ Bir diğer yandan Hammurabi Kanunları, hukuk düzenini ortaya koyan ilk belgeler olarak kabul edildiğinden, insan haklarıyla ilişkilendirilmektedir. ${ }^{75}$

İnsan hakları, elbette ki pratikteki uygulamaların dışında düşünürlerin fikirlerinde de yer almaktadır. Her ne kadar orta çağda kilise insan hakları ve özgürlük düşüncelerini baskılamış olsa da bazı din adamları bu konularda fikir yürütmüşlerdir. ${ }^{76}$ Thomas Aquinas ve Padovalı Marsilius orta çağda insan hakları konusunda önemli iki isimdir. Aquinolu Thomas, temelde

70 Michael Haas, International Human Rights: A Comprehensive Introduction, Routledge, 2014, s. 2.

71 Mustafa Erdoğan, İnsan Hakları Teorisi ve Hukuku, 2. Baskı, Orion Kitabevi, 2011, s. 24.

72 Michael Freeman, Human Rights, John Wiley \& Sons, 2017, s. 50.

73 Kemal Gözler, İnsan Hakları Hukuku, 2. Baskı, Ekin Basım Yayın Dă̆ıtım, 2018, s. 126.

74 Rona Aybay, İnsan Hakları Hukuku, 3. Bask1, İstanbul Bilgi Üniversitesi Yayınları, 2017, s. 26.

75 Freeman, s. 48.

76 Ahmet Mumcu/Elif Küzeci, İnsan Hakları \& Kamu Özgürlükleri: Kavramlar, Evrensel ve Ulusal Gelişimleri, Bugünkü Durumları, 3. Baskı, Savaş Yayınları, 2003, s. 49. 
"zalim ve keyfi iktidarı önleme kaygısı"ndan hareket etmektedir. ${ }^{77}$ Aquinolu Thomas'ın görüşlerine göre direnme hakkı, Tanrısal kanunlara uymayan ve doğal yasalara aykırı kanunlar çıkartan hükümdara karşı kullanılabilecek bir hak olarak tanımlanmıştır. ${ }^{78}$ Her ne kadar bu yönüyle haklarını savunan bir düşünür gibi görünse de Gözler bu durumun sanıldığ1 gibi olmadığını vurgulamaktadır. Zira Aquinolu Thomas, "din ve vicdan özgürlügünü kesin olarak reddetmektedir."’9 Padovalı Marsilius'un düşüncelerinde dikkat çeken yön ise, Aquinolu Thomas'ın tam aksine, açık bir şekilde din ve vicdan özgürlüğünü savunmasıdır. Ayrıca Marsilius, kilise ile devlet arasında ayrıma gidilmesini önermekte ve o dönemde tartışılması bile zor olan bir konuda, devletin mutlak iktidarı konusunda, bu mutlakıyetin sınırlanması gerektiğini ifade etmektedir. ${ }^{80}$

Daha sonraki yüzyıllarda John Locke ve Jean-Jacques Rousseau gibi yazarlar doğal hukuk yaklaşımı sebebiyle, Beccaria gibi yazarlar da ceza hukuku alanında işkence yasağı gibi öncü yaklaşımları sebebiyle Aybay tarafindan insan haklarının oluşumunda katkısı olan isimler olarak zikredilmektedir. ${ }^{81}$ Her ne kadar Antik Yunan, Mezopotamya, Çin ve Hindistan uygarlıklarında tarihsel temelleri bulunduğu anlatılsa da insan hakları, felsefi temel olarak doğal hukuk yaklaşımına dayandırılmaktadır. ${ }^{82}$ Özellikle Locke'un doğal hukuk yaklaşımı doğrultusunda, bazı hakların insan eliyle ortaya çıkmış haklar olmadığı, aksine bizatihi daha üstün bir hukukun sonucu olduğu vurgulanmaktadır. Bu kapsamda anılan haklar (yaşama hakkı, özgürlük hakk1 ve mülkiyet hakkı) temel haklar olarak görülür ve insanların bu doğal hakları dokunulmaz ve devredilemezdir. ${ }^{83}$ Locke'un düşüncesinde doğa durumu, özgürlüğün ve eşitliğin olduğu bir yapıyı ifade eder ve doğa durumundaki doğal hukuk Tanrı'nın bir eseridir. Böylece doğal hukuk, diğer hukuk kuralları içerisinde en üst noktaya yerleşir ${ }^{84} \mathrm{Bu}$ yönüyle de doğal

77 Münci Kapani, Kamu Hürriyetleri, 7. Bask1, Yetkin Yayınları, 1993, s. 23.

78 Kapani, s. 24.

79 Gözler, s. 131.

80 Kapani, s. 26; Gözler, s. 131.

81 Aybay, s. 26.

82 Şeref Ünal, Temel Hak ve Özgürlükler ve İnsan Hakları Hukuku, Yetkin Yayınları, 1997, s. 28.

83 Shaw, s. 204; Fatih Türe, "İnsan Haklarının Normatif Kökeni”, 2014, 32, Sosyal Bilimler Enstitüsü Dergisi, s. 158.

${ }^{84}$ Fatih Demirci, Meşru Devletin İnşası: Klasik Toplum Sözleşmesi Kuramlarında Birey- 
hukukun bir parçası olan temel haklar, Tanrısal bir kökene sahip olduğundan kıyaslandığı diğer beşerî normlardan üstün bir kategoride yer alır. Bir diğer taraftan, Thomas Paine de devletin amacını anlattığı eserinde bu amacın "her insanın doğuştan sahip olduğu inkâr edilemez haklarını korumak olduğunu" ifade etmiştir. ${ }^{85}$

İnsan haklarına yönelik hukuki belgelerin gerçekten ilk olarak hangi tarihlerde ortaya çıktığ 1 hususu ise tartışmalıdır. $\mathrm{Bu}$ anlamda, örneğin 1215 yılında İngiltere'de Kral John ve toprak sahipleri arasındaki ilişkileri düzenlemek için hazırlanan Magna Carta Libertatum'un, bazı kesimlerce insan haklarının öncü temel belgelerinden olduğu iddia edilmektedir. ${ }^{86}$ Ancak bu belgenin insan haklarının atası olduğu iddiası, bizim bakış açımızdan gerçeği yansitmamaktadır. Zira Magna Carta, bir insan hakları belgesi olmaktan ziyade, kral ile soylu toprak sahipleri arasındaki ilişkileri düzenleyen bir taviz belgesidir. Daha gerçekçi bir diğer açıklamaya göre ise, insan hakları hukukuna yönelik somut çıktılar, Kapani'nin de insan hakları doktrininin oluştuğu dönem olarak ifade ettiği 17 . ve 18 . yüzyıllarda elde edilmiştir. ${ }^{87}$ Gerçekten de tam da bu tarihlerle uyumlu olarak insan haklarının ilk defa anayasalarda veya anayasa benzeri yasal belgelerde yer alması İngiltere'de başlamıştır. Bu bağlamda aşağıda İngiltere, Amerika ve Fransa olmak üzere üç ülkede insan haklarının gelişimine ilişkin belgelerden bahsedilecektir.

İngiltere'nin insan haklarına anayasa ve benzeri belgelerde yer veren ilk ülke olduğu iddiası, 1628 Haklar Dilekçesi (Petition of Right) ve 1689 Temel Haklar Bildirisi'nden (Bill of Rights) ileri gelmektedir. Haklar Dilekçesi'nde parlamento halk ayaklanmaları sebebiyle kraldan bazı taleplerde bulunmuştur. $\mathrm{Bu}$ taleplerin insan hakları ile ilişkilendirilebilecek örnekleri keyfi tutuklamanın yasaklanması ve ev sahibinin rızası olmadan askerlerin evlerde konaklamasının yasaklanmasıdır. Ancak bu dilekçeyi kabul eden kral, verdiği sözleri yerine getirmemiştir. ${ }^{88} 1689$ Temel Haklar Bildirisi ise vatandaşların kral tarafından doğrudan dokunulamaz bazı temel haklara sahip olduğunu ifade

Devlet İlişkisi (Hobbes, Locke, Rousseau), 1. Bask1, Orion Akademi, 2021, s. 252.

85 Erdoğan, s. 127.

86 Aybay, s. 31.

87 Münci Kapani, İnsan Haklarının Uluslararası Boyutları, 2. Baskı, Bilgi Yayınevi, 1991, s. 19.

88 Aybay, s. 32-33. 
etmektedir ve yasa olarak kabul edilmektedir. ${ }^{89} \mathrm{Bu}$ belge ile vatandaşların her türlü hak ve özgürlüklerini talep etme hakkı tanınmıştır. Ayrıca bu temel hak ve özgürlükler, insanların her türlü tehlikeden uzak olmasını ve zarar görmesinin engellenmesini koruma altına almaktadır. ${ }^{90} \mathrm{Bu}$ temel haklar arasında özellikle adil yargılanma ve mülkiyetin korunması dikkat çekicidir. ${ }^{91}$

İkinci olarak, Virginia Haklar Bildirisi (1776), Amerikan Bağımsızlık Bildirgesi (1776) ve Amerika Birleşik Devletleri (ABD) Anayasası (1787) okyanusun diğer tarafinda insan hakları hukukunun gelişimi açısından muazzam katkılar sağlamıştır. İfade edilen ilk iki belge, açık bir şekilde insanların yaşama hakkını, mülkiyet hakkını ve mutlu olma hakkını ifade etmektedir. Yine bu bağlamda devletin görevi de bu hakların korunması ve güvence altına alınmasını sağlamaktır. ${ }^{92}$ Ayrıca ilginç bir nokta olarak da Bağımsızlık Bildirgesi, insanların yaratıcıdan gelen doğal hakları olduğunu da ifade etmektedir. ${ }^{93}$ Erdoğan'a göre bu iki belge, "insan hakları konusunda tutarlı bir siyasal felsefeye dayanan ilk bildiriler idi." ${ }^{94} 1787^{\prime}$ 'de hazırlanan $\mathrm{ABD}$ anayasasının ilk metni hak ve özgürlükler konusuna yer vermemektedir. Ancak 1791 yılında yapılan değişiklik ile, anayasaya yeni maddeler eklenmiştir. İlk On Ek (First Ten Amendments) olarak bilinen bu değişiklikle, dini özgürlükler, ifade özgürlüğü, kişi hürriyeti ve konut dokunulmazlığı gibi hak ve özgürlükler tanımlanmıştır. ${ }^{95}$

18. yüzy1l kapanmadan ortaya çıkan sonuncu önemli belge ise 1789 tarihli Fransız İnsan ve Yurttaş Hakları Bildirisi'dir. Bu bildiri de açık bir şekilde doğal hukuk anlayışından beslenmektedir. ${ }^{96} \mathrm{Bu}$ belge, Doğan'a göre Avrupa'da bireysel hakların hareket noktası olarak tarihte yerini almıştır. ${ }^{97}$ $\mathrm{Bu}$ bağlamda bildiri, insan haklarının gelişiminde de önemli bir yere sahiptir. 1789 Bildirisi ile, tüm insanların eşit haklarla özgür olarak doğduğu ve böyle

\footnotetext{
89 Ünal, s. 32; Aybay, s. 33.

90 İlyas Doğan, İnsan Hakları Hukuku Ders Kitab1, 1. Bask1, Astana Yayınları, 2013, s. 62.

91 Erdoğan, s. 128; Paul Gordon Lauren, The Evolution of International Human Rights: Visions Seen, 3. Bask1, University of Pennsylvania Press, 2011, s. 17.

92 Ünal, s. 32.

93 Aybay, s. 35.

94 Erdoğan, s. 129.

95 Aybay, s. 35-36.

96 Aybay, s. 37.

97 Doğan, s. 80.
} 
kalacağ1, özgürlük ve güvenlik gibi hakların bu haklar arasında sayıldığ1 ve tüm bu hakların evrensel olduğu ifade edilmiştir. Ayrıca kanun önünde eşitlik ve keyfi tutuklamanın yasaklanması gibi kurallar da bu bildirinin insan haklarına getirdiği önemli yenilikler ve katkılar arasında sayılmaktadır. ${ }^{98}$

\section{B. Uluslararası İnsan Hakları Hukukunun Tarihsel Gelişimi}

İnsan hakları hukukunun konusu insan haklarıyla ilişkili olan hukuk kurallarıdır, dolayısıyla bizatihi insan haklarının incelendiği bir alan değildir. ${ }^{99}$ $\mathrm{Bu}$ kapsamda değerlendirildiğinde, insan hakları hukuku konusunda iç (ulusal) insan hakları hukuku ve uluslararası insan hakları hukuku ayrımı yapılmaktadır. ${ }^{100}$ Uluslararası insan hakları hukukunun gelişimi, insan hakları ve insan hakları hukukunun gelişiminden daha farklı bir tarihsel çizgide ilerlemiştir. Zira bu farklılık doğal bir gereklilikten de ortaya çıkmaktadır. Uluslararası insan hakları hukukundan bahsedebilmek için, öncelikle genel uluslararası hukuk prensiplerinin yerleşmiş olduğu egemen-eşit devletler arası bir düzenden söz edilmelidir. Her ne kadar bu düzenin yerleşmesine kadar insan haklarının kavramsal ve pratik yönleriyle geliştiği durumlar olmuşsa da bu gelişim uluslararası insan hakları hukukunun varlığına ancak bir altyapı oluşturmuştur.

Bu bağlamda 20. yüzyılın bir ürünü ve dünya savaşlarının bir sonucu olan çağdaş uluslararası insan hakları hukukunun, BM Şartı'nın kabulü, Nuremberg ve Tokyo savaş suçları yargılamaları ve İHEB ile doğduğu genellikle kabul edilmektedir. ${ }^{101}$ BM Şartı'na kadar bireysel haklar ile devletlerin hakları birbirlerinden ayrı olarak ifade edilmemiştir. ${ }^{102}$ Bir başka ifadeyle, bireysel haklar devletin hakları ile özdeş olarak yorumlanmıştır. Ancak ulus-devletlerin birey-devlet ayrımını ortaya çıkartmasıyla bu durum değişmiştir. İnsan hakları kavramı, devletle birey arasındaki ilişkileri düzenler bir mahiyette anlaşılmış ve uluslararası hukukun önemli bir yapı taşı olarak gündeme gelmiştir. ${ }^{103} \mathrm{Bu}$

\footnotetext{
98 Lauren, s. 20.

99 Gözler, s. 35-36.

100 Gözler, s. 43.

101 Jack Donnelly/Daniel J. Whelan, International Human Rights, 5. Bask1, Routledge, 2018; Freeman, s. 47; Charles R. Beitz, The Idea of Human Rights, Oxford University Press, 2011, s. 14.

102 Ali İbrahim Akkutay, "İnsan Hakları Hukukunun Pozitivist Yönünü Oluşturan İlgili Uluslararası Antlaşmaların Feminist Yaklaşıma Etkisi”, 2017, Özel Sayı, Türkiye Barolar Birliği Dergisi, s. 18.

103 J. Samuel Barkin, "The Evolution of the Constitution of Sovereignty and the Emergence of
} 
sebeple de insan hakları kavramı genellikle uluslararası hukuk çerçevesinde anlam kazanmakta ve bu minvalde yorumlanmaktadır. ${ }^{104}$

Her ne kadar ulus-devletler uluslararası insan hakları hukukunun temel uygulayıcis1 olsa da uluslararası hukukun genel prensiplerinden ayrılan bir yönüyle insan hakları hukuku devletler arasındaki ilişkileri değil, devlet ile birey arasındaki ilişkileri düzenlemektedir. ${ }^{105}$ Dolayısıyla BM Şartı'nın kabul edildiği yıl olan 1945 yılında, insan hakları meselesi bir ulusal mesele olmaktan çıkıp uluslararası hukukun konusu olmaya başlamıştır. ${ }^{106} \mathrm{Bu}$ özelliğiyle de BM Şartı, bazı yazarlar tarafindan uluslararası insan hakları hukukunun kurucu unsuru olarak anılmaktadır. ${ }^{107}$ Bununla uyumlu bir şekilde 20. yüzyıl, özellikle de ikinci yarısı, insan hakları konusundaki gelişmeler nedeniyle bazı yazarlar tarafından "insan hakları çağı" olarak adlandırılmıştır. ${ }^{108}$

Uluslararası hukukun bir dalı olan uluslararası insan hakları hukukunun kaynaklarının da uluslararası hukuktan farklı olmayacağı aşikârdır. ${ }^{109}$ Çalışmanın önceki kısımlarında da ifade edildiği üzere UAD Statüsü'nün 38/1 hükmü bu kaynakları sıralamaktadır. Uluslararası hukuk için geçerli olan bu kaynaklar aynı zamanda uluslararası insan hakları hukuku için de geçerlidir. Nitekim bu çalışmanın temel konusu da uluslararası insan hakları hukukunun bir kaynağı olarak örf ve âdet hukukudur. Ancak uluslararası insan hakları hukukunun gelişimine bakılırken muhakkak ki yazılı kaynaklar da göz önünde bulundurulmalıdır. İnsan Hakları Evrensel Beyannamesi (1948), Soykırım Suçunun Önlenmesi ve Cezalandırılması Sözleşmesi (1948), Her Türlü Irk Ayrımcılığının Ortadan Kaldırılmasına İlişkin Uluslararası Sözleşme (1965) ve Medeni ve Siyasi Haklar Uluslararası Sözleşmesi (1966) gibi pek çok temel sözleşme uluslararası insan hakları hukukunun temel dayanak noktalarını

Human Rights Norms", 1998, 27(2), Millennium, s. 229.

104 Tony Evans, "International Human Rights Law as Power/Knowledge”, 2005, 27(3), Human Rights Quarterly, s. 1046.

105 Olivier De Schutter, International Human Rights Law: Cases, Materials, Commentary, Cambridge University Press, 2010, s. 11.

106 David P. Forsythe, Human Rights in International Relations, Cambridge University Press, 2017, s. 3.

107 Thomas Buergenthal, "The Normative and Institutional Evolution of International Human Rights”, 1997, 19(4), Human Rights Quarterly, s. 703.

108 Upendra Baxi, The Future of Human Rights, Oxford University Press, 2007, s. 1.

109 Gözler, s. 480. 
oluşturmaktadır. ${ }^{110}$ Burada sayılan temel kaynaklar, BM sistemi içerisinde oluşturulmuş yazılı kaynaklar olup, bu sözleşmeler insan haklarını evrensel ölçütte güvence altına alan dayanak noktalarıdır. ${ }^{111}$

Bu kapsamda değinilecek ilk belge olan BM Şartı'nda insan haklarına ayrıntılı bir yer verilmese de bu belgede kavramın ruhu yer almaktadır. ${ }^{112}$ Bir başka ifadeyle, her ne kadar hazırlık sürecinde insan haklarına ilişkin bir bölümün eklenmesi dile getirilmişse de insan hakları kavramının detaylı bir sınıflandırmasına BM Şartı'nda değinilmemiştir. ${ }^{113}$ Dolayısıyla BM Şartı, insan haklarını listeleyen bir belge değildir. Bu sebeple BM Şartı sadece genel prensipler içerdiğinden, başlı başına insan haklarına yönelik olan daha detaylı düzenlemelere ihtiyaç duyulmuştur. ${ }^{114} \mathrm{Bu}$ doğrultuda BM kapsamında İnsan Hakları Komisyonu kurularak bu düzenlemenin hazırlıkları başlamıştır. ${ }^{115}$

Bu hazırlıklar sonucunda ortaya çıkan İHEB, 10 Aralık 1948 tarihinde kabul edilmiş temel insan hakları belgelerinden biridir. $\mathrm{Bu}$ belge, insan haklarıyla ilgili geniş bir kapsama sahiptir. ${ }^{116}$ Ancak Gözler'e göre, denetim sistemi öngörmediğinden dolayı bu belgenin bağlayıc1lığı da kısıtlı kalmıştır. ${ }^{117}$ Ayrıca İHEB, zorlayıcı bir mekanizma önermemesi yönüyle de eleştirilere maruz kalmıştır. ${ }^{118}$ İHEB' in bu niteliği hiç şüphesiz ki BM Şartı uyarınca bağlayıcı değil, yalnızca tavsiye niteliğinde kararlar alabilen Genel Kurul tarafından kabul edilmiş bir karar olmasından ileri gelmektedir. Her ne kadar İHEB bağlayıcı değil, tavsiye niteliğinde olsa da bu durum İHEB'in genel bir

110 Buergenthal, "The Normative and Institutional Evolution of International Human Rights", s. 705; Diğer insan hakları hukuku belgeleri için bkz. The Core International Human Rights Treaties, United Nations, 2014.

111 Tacettin Çalık, "Birleşmiş Milletler İnsan Hakları Sözleşmeleri Kapsamında İnsan Haklarının Korunması”, 2016, 24(1), Selçuk Üniversitesi Hukuk Fakültesi Dergisi, s. 70.

112 Steven Greer, The European Convention on Human Rights: Achievements, Problems and Prospects, Cambridge University Press, 2006, s. 9.

113 Johannes Morsink, The Universal Declaration of Human Rights: Origins, Drafting, and Intent, University of Pennsylvania Press, 1999, s. 1.

114 Josef L. Kunz, "The United Nations Declaration of Human Rights”, 1949, 43(2), American Journal of International Law, s. 318.

115 Kapani, İnsan Haklarının Uluslararası Boyutları, s. 23.

116 Erdoğan, s. 131.

117 Gözler, s. 475-476.

118 Thomas Risse/Stephen C. Ropp/Kathryn Sikkink, The Power of Human Rights: International Norms and Domestic Change, 7. Bask1, Cambridge University Press, 2007, s. 207. 
anlayışı ortaya koyan başarılı bir çaba olduğu gerçeğini değiştirmemektedir. ${ }^{11}$ İHEB'in birçok normu artık uluslararası örf ve âdet hukukunun yerleşik kurallarını içeren bağlayıcı kurallara dönüşmüştür. ${ }^{120}$ Diğer taraftan İHEB, açık bir şekilde ülkelerin anayasal düzenlemelerinde insan hakları anlayışına yer verilmesinin öncüsü olmuştur. ${ }^{121} \mathrm{Bu}$ anlamda özetle söylenebilir ki uluslararas1 insan hakları hukukunun gelişimi BM Şartı ve İHEB'in kabulünden sonra hız kazanmıştır. Ancak uluslararası insan hakları hukuku rejiminde BM gibi evrensel bir sistem dişında bölgesel sistemler de bulunmaktadır. Bu sistemlere örnek olarak Afrika ${ }^{122}$, Amerika ${ }^{123}$ ve Avrupa ${ }^{124}$ insan hakları hukuku sistemleri verilebilir. Bahsedilen üç bölgesel sistemin de kendi içerisinde insan haklarına ilişkin sözleşme, kurum ve düzenlemeleri bulunmaktadır.

119 Aybay, s. 51-52; Egon Schwelb, "The Influence Of The Universal Declaration Of Human Rights On International And National Law", 1959, 53, Proceedings of the American Society of International Law at Its Annual Meeting (1921-1969), s. 218.

120 Hurst Hannum, "The Status of the Universal Declaration of Human Rights in National and International Law", 1995, 25, Georgia Journal of International and Comparative Law, s. 289; Hurst Hannum, "The UDHR in National and International Law", 1998, 3(2), Health and Human Rights, s. 145.

121 Jose A. Lindgren Alves, "The Declaration of Human Rights in Postmodernity", 2000, 22, Human Rights Quarterly, s. 478.

122 Organization of African Unity (OAU), Convention Governing the Specific Aspects of Refugee Problems in Africa ("OAU Convention"), 10 September 1969, 1001 U.N.T.S. 45; Organization of African Unity (OAU), African Charter on Human and Peoples' Rights ("Banjul Charter"), 27 June 1981, CAB/LEG/67/3 rev. 5, 21 I.L.M. 58 (1982); Organization of African Unity (OAU), African Charter on the Rights and Welfare of the Child, 11 July 1990, CAB/LEG/24.9/49 (1990); African Union, Protocol to the African Charter on Human and People's Rights on the Rights of Women in Africa, 11 July 2003.

${ }^{123}$ Organization of American States (OAS), Charter of the Organisation of American States, 30 April 1948; Inter-American Commission on Human Rights (IACHR), American Declaration of the Rights and Duties of Man, 2 May 1948; Organization of American States (OAS), American Convention on Human Rights, "Pact of San Jose", Costa Rica, 22 November 1969; Organization of American States (OAS), Inter-American Convention to Prevent and Punish Torture, 9 December 1985, OAS Treaty Series, No. 67; Organization of American States (OAS), Additional Protocol to the American Convention on Human Rights in the Area of Economic, Social and Cultural Rights ("Protocol of San Salvador"), 16 November 1999, A-52; Organization of American States (OAS), Protocol to the American Convention on Human Rights to Abolish the Death Penalty ("Pact of San Jose"), 8 June 1990, OAS Treaty Series, $\mathrm{N}^{\circ} .73$; Organization of American States (OAS), Inter-American Convention on Forced Disappearance of Persons, 9 June 1994; Organization of American States (OAS), Inter-American Convention on the Prevention, Punishment and Eradication of Violence against Women ("Convention of Belem do Para"), 9 June 1994.

124 Avrupa Konseyi (1949), Council of Europe, European Convention for the Protection of Human Rights and Fundamental Freedoms, as amended by Protocols Nos. 11 and 14, 4 November 1950, ETS 5; Avrupa İnsan Hakları Mahkemesi (1959), Avrupa İnsan Hakları Komisyonu, Avrupa İnsan Hakları Divanı, Helsinki Sonuç Belgesi (1975). 


\section{Uluslararası İnsan Hakları Hukukunun Genel Nitelikleri}

Uluslararası insan hakları hukukunun finans ve ticaret gibi uluslararası hukuk alanlarına kıyasla görece daha zayıf olduğu doktrinde ileri sürülen görüşlerden birisidir. ${ }^{125}$ Ancak yine de uluslararası insan hakları hukukunun bağlayıcı kuralları, 1970'lerin ortalarından 1980'lerin ortalarına kadar artış gösteren bir eğilimde olmuştur. ${ }^{126}$ Schutter'e göre uluslararası insan hakları hukukuna ilişkin sözleşmeleri imzalamış veya onaylamış olsunlar veya olmasınlar, tüm devletler uluslararası olarak tanınan insan haklarına sayg1 duymak konusunda bağlıdırlar. ${ }^{127}$ Ancak yine de genel bir bakışla Schutter'e göre insan haklarının uluslararası hukukta temsili konusunda bugün başlıca üç sorunlu alan vardır. Birincisi, tüm insan hakları sözleşmelerinin evrensel bir şekilde onaylanması ve taraf olunması konusunda bugün yeterli seviyeye gelinememiştir. İkincisi, devletler antlaşmaları kabul etmeleri ve onaylamaları halinde bile çekinceler koyabilmektedir. Sonuncusu ise, ulus-devletler insan hakları konusunda aslında tek muhatap alınacak tarafolarak kabul edilmektedir. Bu bağlamda örneğin uluslararası örgütler, ulus-ötesi şirketler gibi devlet dış1 aktörlere de bu yükümlülüklerin genişletilmesi doktrinde tartışılmaktadır. ${ }^{128}$

Uluslararası insan hakları hukuku normları önemli bir özellik olarak iç (ulusal) hukuku da yakından ilgilendirmektedir, zira insan hakları öncelikle devletlerin kendi uhdelerinde korunmaktadır. ${ }^{129}$ Türkiye (Anayasa md. 90) örneğinde görüldüğü gibi, bazı devletler uluslararası sözleşmeleri normlar hiyerarşisinde kanunların üzerine koymakta, kanunlarla çelişmesi halinde ise uluslararası sözleşmelerin geçerli olduğunu kabul etmektedir. Bu bağlamda uluslararası insan hakları hukukunun da ulusal hukuk düzenine etkisinin olduğunu söylemek yanlış olmayacaktır. ${ }^{130}$ Özkan'ın ifadesine göre de "insan hakları hukuku yönünden ulusal hukuka gönderme yapmak, istisna değil, kuraldır."131

125 Eric Neumayer, "Do International Human Rights Treaties Improve Respect for Human Rights?", 2005, 49(6), Journal of Conflict Resolution, s. 926.

126 Ellen L. Lutz/Kathryn Sikkink, "International Human Rights Law and Practice in Latin America", 2000, 54(3), International Organization, s. 633.

127 Schutter, s. 49.

128 Schutter, s. 55.

129 Ünal, s. 102.

130 Mahmut Göçer, "Uluslararası İnsan Hakları Andlaşmalarının Bağdaşmazlığı Sorunu ve Uluslararas1 Hukuk", 2001, 56(3), Ankara Üniversitesi SBF Dergisi, s. 48.

131 Iş1 Özkan, "Uluslararası Hukuk - Ulusal Hukuk İlişkileri”, 2013, 8(Özel), Journal of Yaşar 
Shaw'a göre uluslararası insan hakları hukukunun bazı temel ilkeleri bulunmaktadır. Bunlar ulusal yetki, iç hukuk yollarının tüketilmesi kuralı ve hakların üstünlükleridir. ${ }^{132}$ Ulusal yetki konusu, BM Şartı'nda düzenlenmiş olan devletlerin egemen-eşitliği ilkesinden ileri gelmektedir. Bu ilke gereği, devletler kendi iç işlerinde tek egemen ve yetkilidir ve devletlerin iç işlerine başka devletler ve uluslararası örgütler tarafindan müdahale edilemez. ${ }^{133}$ Ancak bu kural devletler tarafından uluslararası insan hakları açısından yeniden yorumlanmıştır. $\mathrm{Bu}$ yorumlamada, örneğin "bir devletin bir uluslararası prosedür gereğince bireylerin başvuru hakkını kabul ettiği durumlarda, söz konusu devletin bu tür bir hakkın uygulanmasının kendi iç işlerine müdahale teşkil ettiğini iddia edemeyeceği de açıktır." 134 Dolayısıyla "uluslararası hukukun veya antlaşmaların kapsamına giren konular, devletlerin özel yetki alanının (iç hukukunun) sınırları içinde sayılamazlar." ${ }^{135}$ Reisman'ın ileri sürdüğü üzere, bugün neredeyse hiçbir yazar, ulusal düzeydeki insan haklarının münhasıran ilgili devletin ülkesel yetki alanı dahilinde olduğunu ve dolayısıyla uluslararası hukuktan izole edildiği iddiasını desteklememektedir. ${ }^{136}$

Diğer taraftan Gözler'in de ifade ettiği gibi, düalist sistemlerde uluslararası insan hakları hukuku kurallarının iç hukukta geçerli kurallar haline gelebilmeleri için öncelikle birer iç hukuk kuralı haline getirilmeleri gerekmektedir. ${ }^{137}$ Türkiye gibi monist sistem uygulayan ülkelerde ise, uluslararası hukuk kuralları ile iç hukuk kurallarının arasında bir ayrım yapılmaz. Dolayısıyla uluslararası hukuk sözleşmelerine taraf olmak ve bunu onaylamakla birlikte ayrıca bir iç hukuk düzenlemesine ihtiyaç duyulmaksızın bu kurallar iç hukuk kuralı haline gelir. Bir diğer ifadeyle, uluslararası insan hakları hukuku sözleşmeleri, monist sistem uygulayan ülkelerde onaylanmalarını müteakiben birer iç hukuk kuralı haline gelirler. ${ }^{138}$

University s. 2141.

132 Shaw, s. 207-208.

133 U.N. Charter, 24 October 1945, 1 UNTS XVI., art. 2/7.

134 Shaw, s. 207.

135 Kapani, İnsan Haklarının Uluslararası Boyutları, s. 92.

136 Michael Reisman, "Sovereignty and Human Rights in Contemporary International Law", 1990, 84(4), American Journal of International Law, s. 869. Bkz. Kelly Kate Pease/David P. Forsythe, "Human Rights, Humanitarian Intervention, and World Politics", 1993, 15 Human Rights Quarterly, s. 296; Thomas Buergenthal, "The Evolving International Human Rights System", 2006, 100(4), American Journal of International Law, s. 787.

137 Gözler, s. 478.

138 Gözler, s. 478-479. 
İkinci temel ilke uyarınca, uluslararası hukukta genel anlamda geçerli bir kural olarak, bireylerin iç hukuk yollarını tüketerek uluslararası hukuka başvurmaları esastır. Bu uygulama uluslararası insan hakları hukuku açısından da geçerlidir. ${ }^{139}$ Örneğin bölgesel bir insan hakları sistemi olan ve temel olarak Avrupa İnsan Hakları Sözleşmesi'ne dayanan Avrupa sisteminde, "[Avrupa İnsan Haklar1] Mahkemesi'ne ancak, uluslararası hukukun genel olarak kabul edilen ilkeleri uyarınca iç hukuk yollarının tüketilmesinden sonra . . . başvurulabilir." ${ }^{140}$ Benzer şekilde yine bir bölgesel sistem olan Amerikalılar arası insan hakları sisteminde, taraflar arasındaki sözleşmeyle tanınan bir insan hakkı ihlali için yapılacak başvuru, "iç hukuk kapsamındaki hukuk yollarının, genel kabul görmüş uluslararası hukuk ilkelerine uygun olarak takip edilmesi ve tüketilmesine" kadar beklemek durumundadır. ${ }^{141}$

Son olarak hakların üstünlükleri kuralı ise bazı temel hakların olağanüstü durumlarda ve belli koşullar altında kısıtlanabilmesine ilişkindir. Bazı haklar, ülkelerin anayasalarında veya uluslararası sözleşmelerde özel durumlar altında, özellikle olağanüstü hâl dönemlerinde, sınırları belirli usullerle kısitlanabilmekte veya askıya alınabilmektedir. ${ }^{142}$ Ancak askıya alınamayan, özüne dokunulamayan veya müdahale edilemeyen haklar da bulunmaktadır. Uluslararası insan hakları özelinde bunun en açık örnekleri İHEB'de sayıldığı şekliyle yaşama hakk1, işkenceye ve insanlık dışı aşağılayıcı ceza ve işlemlere uğramama hakkı, köle ve kul olarak tutulmama hakkı ve cezaların geriye yürümezliği ilkesi olarak ifade edilebilir. ${ }^{143}$ Dolayısıyla bu tür hakların, haklar arası bir hiyerarşide üstün haklar olduğu kabul edilmelidir. ${ }^{144}$

\section{ULUSLARARASI ÖRF VE ÂDET HUKUKU ILE ULUSLARARASI INSAN HAKLARI HUKUKU İLİŞKISII}

Genel olarak bakıldığında uluslararası örf ve âdet hukukunun uluslararası insan hakları hukuku ile olan ilişkisinde üç temel tartışmalı konu

\footnotetext{
139 Shaw, s. 208.

140 Council of Europe, European Convention for the Protection of Human Rights and Fundamental Freedoms, as amended by Protocols Nos. 11 and 14, 4 November 1950, ETS 5, art. 35 .

141 Organization of American States (OAS), American Convention on Human Rights, "Pact of San Jose”, Costa Rica, 22 November 1969, art. 46.

142 Kapani, İnsan Haklarının Uluslararası Boyutları, s. 113.

143 Kapani, İnsan Haklarının Uluslararası Boyutları, s. 114.

144 Shaw, s. 208-9.
} 
bulunmaktadır. Bunlardan birincisi, uluslararası insan hakları hukukunun örf ve âdete mi, sözleşmelere mi, yoksa her ikisine birden mi dayalı olduğunu tartışmasıdır. İkinci olarak, uluslararası insan hakları hukukunun erga omnes niteliği doktrinde geniş çaplı tartışmalara sebebiyet vermektedir. Son olarak ise, TWAIL akademisyenleri gibi uluslararası hukuka eleştirel bakış açısına sahip olanların evrensel nitelikte bir uluslararası insan hakları hukukundan bahsedilip bahsedilemeyeceğine ilişkin sorgulamalarıdır. Aşağıda bu tartışmalar doktrindeki görüşler ve içtihat hukuku çerçevesinde ele alınmıştır.

\section{A. Uluslararası Örf ve Âdet Hukukunun İnsan Hakları Hukukuna Kaynak Olması Sorunu}

Uluslararası örf ve âdet hukukunun insan hakları hukukuna katkısı doktrinde tartışmalı bir meseledir. ${ }^{145} \mathrm{Bu}$ tartışmalı ortamda bir taraftan insan hakları hukuku ve uluslararası hukukun kaynakları arasındaki ilişki irdelenmekteyken, diğer taraftan da uluslararası örf ve âdet hukukunun insan haklarını geliştirici yöndeki etkisi vurgulanmaktadır. ${ }^{146}$ Örneğin Henkin, insan hakları hukukunun uluslararası hukuk kaynaklarını ciddi biçimde etkilemiş ve onları bir anlamda yeniden şekillendirmiş olduğunu ileri sürmektedir. ${ }^{147}$ Henkin'in bu görüşü, uluslararası hukukun kaynakları arasında sayılan örf ve âdeti kesin bir dille insan hakları hukukunun kaynakları arasından çıkartmasına ve insan haklarıyla birlikte hukukun artık sadece devletler arası ilişkileri değil insan ve devlet arasındaki ilişkileri de düzenler şekilde dönüştüğünü ifade etmesine dayanmaktadır. ${ }^{148}$

Henkin, örf ve âdeti ve sözleşmeleri (antlaşmaları) uluslararası insan hakları hukukunun kaynakları arasından çıkartırken, yeni bir kaynak yaratmaktadır: sözleşmeden kaynaklanmayan hukuk (non-conventional law). D'Amato ise açık bir dille Henkin'in bu yeni kategorisini eleştirmektedir. Bu eleştiri, Henkin'in insan haklarını evrensel, sözleşmeye ve örf ve âdete

145 Douglass Cassel, "Does International Human Rights Law Make a Difference", 2001, 2, Chicago Journal of International Law, s. 124; Hugh Thirlway, "Human Rights in Customary Law: An Attempt to Define Some of the Issues", 2015, 28, Leiden Journal of International Law, s. 499.

146 Theodor Meron, Human Rights and Humanitarian Norms as Customary Law, Clarendon Press, 1989.

147 Henkin, Human Rights and State Sovereignty, s. 36.

148 Anthony D'Amato, “Human Rights as Part of Customary International Law: A Plea for Change of Paradigms", 1995, 25, Georgia Journal of International and Comparative Law, s. 52; Henkin, "Human Rights and State Sovereignty", s. 44. 
dayanmayan, ama sözleşmeden de kaynaklanmayan hukuk (non-conventional law) olarak tanımlamasından ileri gelmektedir. D'Amatoya göre Henkin'in bu açıklaması çocuksudur ve ikna edicilikten uzaktır. ${ }^{149}$ Zira sözleşmeden kaynaklanmayan, ancak örf ve âdete de dayanmayan hukukun kaynağı ne olacaktır? Henkin'in sözleşmeden kaynaklanmayan hukuk görüşü, kaynağını yetersiz açıklamalarla "liberal ulusal anayasalardan ve jus cogens"ten almaktadır. ${ }^{150} \mathrm{Bu}$ bağlamda Henkin, uluslararası insan haklarının kaynağını ulusal anayasalar olarak değerlendirmektedir. Ona göre uluslararası insan hakları hukuku ve ulusal anayasalar birbirlerini derinden etkilemekte ve birbirlerine benzer yönler ortaya koymaktadır. ${ }^{151}$ D'Amato tarafindan eleştirilen Henkin'in insan hakları hukukuna ilişkin ikinci kaynağı ise jus cogens'tir. Jus cogens, D'Amato'ya göre herhangi bir hukuk normunun kaynağ1 olabilecek bir kavram değildir, zira jus cogens'in nereden geldiği, nasıl ve neden uluslararası hukukun bir parçası olduğu ve hatta gerçekten var olup olmadığı bile tartışmalı bir konudur. ${ }^{152} \mathrm{Bu}$ yönüyle Henkin'in sözleşmeden kaynaklanmayan hukuk görüşüşünde, hukukun kaynağının jus cogens olması da mümkün değildir. Dolayısıyla Henkin'in uluslararası insan hakları hukukunun örf ve âdetle olan ilişkisini reddetmesi, D'Amato'nun da eleştirileri doğrultusunda sağlam temellere dayanmamaktadır.

Diğer taraftan, uluslararası örf ve âdet ile insan hakları arasındaki somut ilişkiyi ileri süren yazarlar da bulunmaktadır. Örneğin Cassel'e göre uluslararası örf ve âdete kaynaklık eden uygulamalar insan hakları halatını oluşturan ipliklerden birisidir. ${ }^{153}$ Buna göre Cassel, diplomatik uygulamaları, uluslararası bildirimleri ve diplomatların ifadelerini uluslararası insan hakları hukukunun gelişimine etki eden kaynaklar arasında saymaktadır. ${ }^{154}$ Benzer şekilde Boucher, örf ve âdet hukukunun özellikle uluslararası insan haklarına ilişkin olarak bir fikir birliği ve dayanışma yarattığını ileri sürerek, örf ve âdeti insan haklarının esas kaynağı olarak adlandırmaktadır. ${ }^{155}$ Nitekim örnek olarak değerlendirildiğinde, işkence ve soykırım gibi konulardaki insan hakları

\footnotetext{
149 D’Amato, Human Rights as Part of Customary International Law, s. 52, 53.

150 D'Amato, Human Rights as Part of Customary International Law, s. 53.

151 Henkin, Human Rights and State Sovereignty, s. 40.

152 D'Amato, Human Rights as Part of Customary International Law, s. 57.

153 Cassel, s, 124.

154 Cassel, s. 124.

155 David Boucher, "The Recognition Theory of Rights, Customary International Law and Human Rights”, 2011, 59(3), Political Studies, s. 755.
} 
ihlalleri evrensel olarak tanınan ve üzerinde fikir birliği bulunan konulardır. ${ }^{156}$ Bir başka açıdan Gözler, uluslararası hukukun kaynakları olarak sayılan unsurları uluslararası insan hakları hukukunun kaynakları olarak da kabul etmektedir. ${ }^{157}$ Ona göre uluslararası insan hakları hukuku, açık bir şekilde uluslararası hukukun bir alt disiplini olarak görüldügünden, uluslararası hukukunun kaynakları için geçerli olan yaklaşımlar doğal olarak uluslararası insan hakları hukuku için de geçerli kabul edilmelidir. Bu bağlamda Gözler'e göre uluslararası örf ve âdet, uluslararası insan hakları hukukunun yazısız bir kaynağı olarak değerlendirilebilir, zira örf ve âdet uluslararası insan hakları hukukunun "bir yardımcı kaynağı değil, asıl kaynağıdır."158

Weisburd ise tartışmaya özgün bir pencereden katılarak insan haklarına yönelik sözleşmelerin aslında insan haklarının evrensel uygulanabilirliğini destekleyecek uluslararası örf ve âdet hukuku kurallarının dayanak noktası olabileceğini ileri sürmektedir. Ona göre, insan hakları sözleşmelerine katılım arttıkça bunların örf ve âdet hukuku kuralları olarak değerlendirilme imkânı artmakta ve böylelikle tüm devletler için bağlayıcı hale gelebilmektedirler. Zira yukarıda da açıklandığı üzere bir uluslararası örf ve âdet hukuku kuralının varlığından bahsetmek için, bu kuralı destekleyecek belirsiz sayıda devletin bu yöndeki uygulamaları ve bu uygulamanın hukuki bir yükümlülükten kaynaklandığı inancı (opinio juris) bir arada bulunmalıdır. $\mathrm{Bu}$ itibarla, uluslararası sözleşmeye taraf olmak genel devlet uygulaması ve opinio juris göstergesi olarak yorumlanabilecektir. Bu bağlamda da bir uluslararası insan hakları sözleşmesine katılımın çok yüksek oranda olması bu sözleşme hükümlerinin uluslararası örf ve âdet hukuku kuralı olarak değerlendirilmesinin ve böylece tüm devletleri bağlayıcı niteliği haiz olmasının önünü açabilir. ${ }^{159}$ Buergenthal da uluslararası alanda birçok devlet tarafindan imzalanan antlaşmaların örf ve âdete dayalı uluslararası insan hakları hukukunu oluşturabileceklerini ifade etmektedir. ${ }^{160}$

Weisburd'a benzer şekilde Hathaway'e göre de hükümetler, sözleşmelere

156 Boucher, s. 762.

157 Gözler, s. 480.

158 Gözler, s. 482 (vurgu eklenmiştir).

159 Arthur M. Weisburd, "The Effect of Treaties and Other Formal International Acts on the Customary Law of Human Rights", 1995, 25, Georgia Journal of International and Comparative Law, s. 123.

160 Thomas Buergenthal, “The Evolving International Human Rights System”, 2006, 100(4), American Journal of International Law, s. 790. 
taraf devletlerin sayısının artmasıyla yeni bir örf ve âdet hukuku kuralı oluşturmayı umuyor olabilirler. ${ }^{161}$ Bir sözleşmenin taraflarının sayısının artmasıyla örf ve âdet hukuku kuralı haline gelen konulara örnek olarak soykırım ve işkence yasakları verilebilir. ${ }^{162}$ Hathaway, bu iki konunun uluslararası hukukun mutlak kuralları olduğunu ve birer örf ve âdet hukuku kuralına dönüşmekle tüm devletleri bağladığını, ancak sözleşmelere taraf olan ülkeler üzerine bir miktar daha yasal yükümlülük yüklediğini ifade etmektedir. ${ }^{163}$

Uluslararası örf ve âdetin mi yoksa sözleşmelerin mi uluslararası insan hakları hukukunun kaynağı olduğuna dair diğer görüş ise, uluslararası insan hakları hukukunun yegâne kaynağı olarak bağlayıcı uluslararası antlaşmaları kabul edenler tarafindan benimsenmektedir. ${ }^{164}$ Zira BM uluslararası insan hakları programının temel yaklaşımına göre de uluslararası insan hakları hukuku sözleşmelere dayalı bir hukuk olmalıdır. ${ }^{165}$ Ancak bu durumda da insan hakları sözleşmelerinin uluslararası insan haklarına gerçekten katkı sağlayıp sağlamadığı hususu tartışmalı hale gelmektedir. ${ }^{166}$ Zira örneğin soykırım ve işkence suçları, en geniş anlamda yasaklanmış olan insan hakları ihlalleri olmasına ve kaynağını uluslararası antlaşmalardan almalarına karşın, bu yasaklar aynı zamanda neredeyse evrensel düzeyde kabul gördüğü için ihlalleri durumunda uluslararası örf ve âdet hukukunun ihlali de gündeme gelmektedir. ${ }^{167}$ Dahası Sohn'a göre, devletler neredeyse hiçbir zaman insan hakları üzerine uluslararası hukuk kuralları üretmemektedirler; bu kurallar doktrin tarafindan yaratılmaktadır. ${ }^{168}$ Diğer taraftan Guzman da uluslararası insan hakları hukuku alanında birçok önemli antlaşmanın olduğunu, ancak bunlardan hangilerinin uluslararası örf ve âdet hukuku kapsamında değerlendirilmek suretiyle imzacı olmayan devletlere de uygulanabilecek

161 Oona A. Hathaway, “Do Human Rights Treaties Make a Difference?”, 2002, 111(8), The Yale Law Journal s. 2010.

162 Hathaway, s. 1965.

163 Hathaway, s. 2014.

164 Cassel, s. 124.

165 Richard B. Lillich, "The Growing Importance of Customary International Human Rights Law”, 1995, 25, Georgia Journal of International and Comparative Law, s. 1.

166 Hathaway, s.1938; Neumayer, s. 925.

167 Hathaway, s. 2002.

168 Louis Sohn, "Sources of International Law", 1995, 25(1), Georgia Journal of International \& Comparative Law, s. 399. 
olduğunun henüz yanıtlanamadığını ileri sürerek, uluslararası antlaşmaların uluslararası insan hakları hukukunun yegâne kaynağı olacağı iddiasının zayıflığına işaret etmektedir. ${ }^{169}$

Hathaway'in çalışmasında ileri sürdüğü istatistiklere bakıldığında, insan hakları konusunda en düşük sıralamalarda listelenen ülkelerin bazılarının antlaşmaları imzalama ve onaylama oranı, insan hakları listelerinde yüksek siralamalarda olanlardan fazla olabilmektedir. ${ }^{170} \mathrm{Bu}$ bağlamda uluslararası insan hakları sözleşmelerinin gerçekten insan haklarına ne kadar etkisi olduğu bir soru işareti oluşturmaktadır. Bununla uyumlu bir şekilde Goodman ve Jinks de insan hakları sözleşmelerinin etkisinin tam olarak bilinemediğine işaret etmektedir. ${ }^{171}$ Her iki durum da istatistiksel olarak insan hakları sözleşmelerinin etkinliğinin ölçülmeye çalışılmasında tatmin edici sonuçlara ulaşılamadığını göstermektedir. İnsan hakları hukukunun kaynağının sadece sözleşmeler olarak alınması durumunda insan haklarının evrensel manada korunmasını sağlamakta ne kadar etkili olunacağı sorusu akla gelmektedir. Zira uluslararası insan hakları hukukunun kaynağını sözleşmelere indirgemek, onları sadece imzacı devletlerle bağlayacak şekilde kısıtlı bir kapsama almak anlamına da gelmektir. Dolayısıyla uluslararası örf ve âdetin insan hakları hukukunun kaynağı olarak değerlendirilmesi, erga omnes niteliğini sağlaması bakımından insan haklarının ruhuyla daha uyumlu bir sonuç doğurmaktadır.

Uluslararası örf ve âdet hukukunun maddi öğesi olan devlet uygulamalarının varlığının tespitinde, Scharf'ın da ifade ettiği üzere ülkelerdeki yasama, yürütme veya yargı erkinin faaliyetlerine dayanılabilir. ${ }^{172}$ $\mathrm{Bu}$ itibarla, uluslararası örf ve âdet hukukunun iç (ulusal) hukukun bir parçası haline getirildiğini gösteren devlet uygulamaları da bulunmaktadır. Örneğin Almanya, Avusturya, İtalya, Japonya, Macaristan, Polonya, Rusya ve Yunanistan gibi ülkeler, doğrudan doğruya anayasalarına koydukları hükümlerle uluslararası örf ve âdet hukukunu normlar hiyerarşisinin en üst basamağına taşımışlardır. ${ }^{173}$ Her ne kadar bu ülkelerdeki anayasal hükümler

\footnotetext{
169 Guzman, s. 119.

170 Hathaway, s. 1999.

171 Ryan Goodman/Derek Jinks, "Measuring the Effects of Human Rights Treaties", 2003, 14(1), European Journal of International Law, s. 183.

172 Scharf, s. 309.

173 Dinah Shelton, "International Law in Domestic Systems", in Karen B. Brown/David V. Snyder (eds.), General Reports of the XVIIIth Congress of the International Academy of Comparative Law, Springer, 2012, s. 521-524.
} 
hep bir ağızdan "uluslararası örf ve âdet hukuku" kavramını kullanmıyor olsalar da esas olarak "uluslararası hukukun genel ilkeleri ve normları" anlamına gelebilecek ifadeler içerdikleri görülmektedir.

Benzer şekilde ulusal içtihatlar da uluslararası örf ve âdet hukukunu iç hukukun bir parçası olarak görme eğilimindedirler. Shelton'un tespitine göre içlerinde Almanya, Arjantin, Avusturya, Fransa, İsrail, İtalya, Japonya, Kanada, Lüksemburg, Polonya, Yeni Zelanda ve Yunanistan'in da olduğu pek çok ülkede ulusal mahkemeler uluslararası örf ve âdet hukukuna sıklıkla atıfta bulunmuş ve iç hukukta uygulanabilir olduğunu kabul etmiştir. ${ }^{174}$ Belirtilmelidir ki Shelton'un örnek olarak ele aldığı davaların hiçbirinde insan hakları konusundaki bir uluslararası örf ve âdet hukuku kuralına özel olarak atıfta bulunulmamıştır. Ancak kanaatimizce bulunulmasına gerek yoktur. Zira yukarıda da değinildiği gibi, uluslararası hukuk ve uluslararası insan hakları hukukunun kaynakları aynıdır ve uluslararası örf ve âdet normları da insan hakları hukuku kurallarına kaynaklık edebilmektedir. Dolayısıyla, mahkemelerin bazı konularda uluslararası örf ve âdet hukukuna atıfta bulunulurken, insan hakları konusunda atıfta bulunmaması için herhangi bir sebep yoktur. Bölgesel bir insan hakları sisteminin yargı organı olarak Avrupa İnsan Hakları Mahkemesi de pek çok içtihadında uluslararası örf ve âdetin insan hakları özelinde kaynaklık edeceğini kabul etmiştir. ${ }^{175}$

Dahas1 2020 yılındaki güncel bir davada Kanada Yüksek Mahkemesi, uluslararası örf ve âdet hukuku ile uluslararası insan hakları hukuku arasındaki bağlantıyı açıkça kuran bir karara imza atmıştır. Söz konusu davada Eritreli işçiler, ülkelerindeki bir madende askerlik yoluyla zorunlu çalışma rejimine süresiz olarak tabi tutulduklarını iddia etmişlerdir. İşçiler aynı zamanda Kanadalı bir şirket olan Nevsun Resources Ltd.'ye ait madende şiddet içeren, zalimce, insanlık dışı ve aşağılayıcı muameleye maruz kaldıklarını ileri sürmüşlerdir. Bu eylemlerin zorla çalıştırma, kölelik, zalimce, insanlık dışı veya aşağılayıcı muamele ve insanlığa karşı suçları yasaklayan uluslararası örf ve âdet hukuku normlarının ihlali olduğunu savunan davacılar, Nevsun aleyhine tazminat talebinde bulunmuşlardır. Nevsun ise yerel mahkemelerin yabancı bir hükümetin egemenlik alanında bulunan bir konuda değerlendirme yapmasını engelleyen devlet işlemi doktrini temelinde davanın düşürülmesini

174 Shelton, s. 521-524.

175 Ineta Ziemele, "Customary International Law in the Case Law of the European Court of Human Rights-The Method", 2013, 12(2), The Law \& Practice of International Courts and Tribunals. 
talep etmiştir. Nevsun, Eritreli işçilerin uluslararası örf ve âdet hukukuna ilişkin iddialarının ise dayanaktan yoksun olduğunu ileri sürmüştür. Önüne gelen davada Yüksek Mahkeme, kölelik, zorla çalıştırma ve zalimce, insanlık dışı ve aşağılayıcı muameleye karşı yasaklar gibi bazı uluslararası insan hakları kurallarının jus cogens statüsünde olduğunu, dolayısıyla bunların herhangi bir istisnaya izin verilmeyen bir uluslararası örf ve âdet hukuku niteliğinde olduğunu ve bu nedenle de herhangi bir yasama sürecine gerek kalmadan Kanada iç hukukuna ab initio dahil olduklarını kabul etmiştir. ${ }^{176}$

Uluslararası örf ve âdet hukuku, sözleşmelerin ortaya çıkışına mı kaynaklık etmektedir yoksa sözleşmeler mi uluslararası örf ve âdet hukuku kurallarına dönüşmektedir sorusunun cevabı her ikisi için de olumlu olabilir. Böyle bir durumda uluslararası insan hakları hukukunun gelişiminde örf ve âdetin yerinin olmayacağını, dahası örf ve âdetin insan hakları hukukunun kaynağı da olamayacağını ileri sürmek pek mümkün görünmemektedir. Zira bir sonraki başlıkta detaylandırılacağı üzere, uluslararası insan hakları hukukunun niteliği gereği tüm devletleri bağlayıcı olması beklenmektedir. $\mathrm{Bu}$ itibarla bağlayıcılık açısından sadece imzacılarını kapsayan sözleşmeler hukuku sisteminde uluslararası insan hakları hukukunun gelişimini tam olarak sağlayamayacağı aşikârdır. Ancak, sözleşmelerin imzacı sayısının artmasıyla birlikte bir genel devlet uygulaması ve opinio juris oluşturması bağlamında sözleşmelerin de insan hakları hukukunun evrensel manada gelişimine katkısı olduğu ileri sürülebilir. Burada önemli olan nokta, sözleşmelerin ancak uluslararası örf ve âdet hukukuna kaynaklık edebilmeleri hasebiyle uluslararası insan hakları hukukunun gelişimine katkı sağlamasıdır. Bu itibarla mevzu bahis tartışmada uluslararası örf ve âdet hukukunun insan hakları hukukunun gelişimine olumlu etki ettiğini söylemek mümkündür. Ancak uluslararas1 insan hakları hukukunun örf ve âdetten nasıl etkileneceğine ilişkin tartışma bu kadar kolay çözüme kavuşturulabilecek bir mesele değildir.

\section{B. Uluslararası İnsan Hakları Hukukunun Erga Omnes Niteliği}

Uluslararası örf ve âdet hukuku ile uluslararası insan hakları hukuku ilişkisindeki ikinci temel mesele, uluslararası insan hakları hukukunun bütün uluslararası topluluğa karşı yükümlülükler içerip içermediğine (yani erga omnes niteliğine) ve içermekte ise uluslararası örf ve âdet hukukun buna ne kadar katkı yaptığına ilişkindir. Uluslararası örf ve âdet hukukunun uluslararası insan hakları hukukunu tüm insanlığa karşı ileri sürülebilecek haklar olarak

176 Nevsun Resources Ltd. v. Araya, 2020 SCC 5 (February 28, 2020). 
genişlettiği düşüncesi kendine hem doktrinde hem de içtihat hukukunda destek bulmaktadır. Her ne kadar Weil erga omnes yükümlülükler kavramının evrensel olarak onaylanmadığını ileri sürmekte ise de ${ }^{177}$ Dinstein'ın da belirttiği üzere bugün uluslararası hukukun yerleşik bir ilkesi olarak kabul edilebilir durumdadır. ${ }^{178}$ Gerçekten de Uluslararası Hukuk Komisyonu tarafindan hazırlanarak BM Genel Kurulu tarafindan 2002 yılında kabul edilen "Uluslararası Hukuka Aykırı Eylemlerinden Dolayı Devletlerin Uluslararas1 Sorumluluğu" belgesi, uluslararası yükümlülüklerin ciddi ihlalleri karşısında bir bütün olarak uluslararası topluma karşı duyulan sorumluluk sistemi yaratmıştır. ${ }^{179}$

Paust'a göre uluslararası insan hakları hukukunun erga omnes niteliği, özellikle 1949 Cenevre Konvansiyonu'nda sayılan haklar ve yasaklamalar ile soykırımın yasaklanması konularında kesinleşmektedir, zira Paust 1949 Konvansiyonu'ndaki haklar ve yasaklamaların açık şekilde diğer uluslararası hukuk kurallarından hiyerarşik olarak üstün olduğunu ifade etmektedir. ${ }^{180} \mathrm{Bu}$ kapsamda Paust, bizim de aşağıda ele alacağımız UAD'nin 1970 Barcelona Traction kararından hareketle, uluslararası hukukun bazı kurallarının "tüm devletlerin meselesi" olduğunu kabul etmekte ve geniş katılımlı antlaşmalardaki kuralların örf ve âdet hukukuna tâbi olması nedeniyle de tüm insanlığa yönelik yükümlülükler içeren erga omnes karakterli temel insan haklarından olduklarını kabul etmektedir. ${ }^{181} \mathrm{Bu}$ itibarla bahsedilen örf ve âdete dayalı insan hakları hukuku kuralları, evrensel olma niteliğini haiz olmaktadır. ${ }^{182}$ Bir diğer taraftan Paust'a paralel şekilde Weisburd'a göre de örf ve âdete dayalı uluslararası insan hakları hukuku normlarının erga omnes olması, bu kuralların ihlâlinin tüm devletleri aynı şekilde etkileyecek

\footnotetext{
177 Prosper Weil, “Towards Relative Normativity in International Law?”, 1983, 77(3), American Journal of International Law, s. 432.

178 Yoram Dinstein, "The erga omnes Applicability of Human Rights”, 1992, 30(1), Archiv des Völkerrechts, s. 16.

179 Official Records of United Nations General Assembly, Fifty-sixth Session, 28 January 2002, UN Doc. A/RES/56/83, art. 48.

180 Jordan J. Paust, "The Complex Nature, Sources and Evidences of Customary Human Rights", 1995, 25, Georgia Journal of International and Comparative Law, s. 152; Bu konuda detaylı bilgi için bkz. Theodor Meron, "The Geneva Conventions as Customary Law”, 1987, 81(2), American Journal of International Law, s. 348-370.

181 Paust, s. 153.

182 Paust, s. 154.
} 
olmasından kaynaklanmaktadır. ${ }^{183}$ Benzer şekilde Erika de Wet ise, bölgesel veya evrensel insan hakları sözleşmelerinden kaynaklanan yükümlülüklerin taraf devletlere karşı erga omnes etkisini kabul etmenin yanı sıra, uluslararası örf ve âdet hukuku olarak kabul edildiği ölçüde de erga omnes etkiye sahip olacağını belirtmektedir. ${ }^{184} \mathrm{Bu}$ anlamda örneğin Her Türlü Irk Ayrımcılığının Ortadan Kaldırılmasına İlişkin Uluslararası Sözleşme ile Medeni ve Siyasi Haklar Uluslararası Sözleşmesi, uluslararası örf ve âdet hukuku statüsü kazandıkları ölçüde erga omnes etkiye sahiptirler. ${ }^{185}$

İçtihat hukukuna bakıldığında ise, bazı insan hakları kurallarının erga omnes niteliği açık şekilde kabul edilmektedir. Örneğin Habré davasında $\mathrm{UAD}$, uluslararası insan hakları hukukunun erga omnes niteliğini açık şekilde ortaya koymuştur. Belçika'nın başvurusu üzerine görülen söz konusu davada UAD, görevi sırasında BM İşkenceye Karşı Sözleşme kapsamındaki yükümlülükleri ihlal ettiği iddia edilen eski Çad Cumhurbaşkanı Hissène Habré'nin Senegal tarafindan gecikmeksizin yargılanması ya da iade edilmesi gerekip gerekmediğine karar vermeliydi. Belçika'nın talebini onaylayan mahkeme, İşkenceye Karşı Sözleşme'nin tüm taraf devletlerinin, kendi topraklarında bulunan ve suçlu olduğu iddia edilen kişiler hakkında kovuşturma başlatma yükümlülüğü olduğuna ve bu yükümlülüğün taraf devletlerin ortak çıkarı olduğuna karar vermiştir. Bu itibarla UAD'ye göre, "erga omnes partes yükümlülüklerin" korunmasında tüm taraf devletlerin "yasal çıkarları" bulunmaktadır. ${ }^{186}$

Bu sonuca ulaşılabilecek bir başka dava ise yine UAD'nin karara bağladığ 1 East Timor davasıdır. ${ }^{187}$ Doğu Timor fiilen Endonezya hakimiyetinde iken, Avustralya'nın Endonezya ile Doğu Timor kıta sahanlığına ilişkin bir antlaşma imzalamasının hukuka aykırı olup olmadığını değerlendirmesi istenen davada, UAD "yasal çıkar" anlayışının aslında geniş yorumlanması gerektiğine dair bazı göstergeler ortaya koymuştur. Davada Portekiz ve Avustralya, UAD

183 Weisburd, s. 108.

184 Erika de Wet, "Jus Cogens and Obligations Erga Omnes", in Dinah Shelton (ed.), The Oxford Handbook of International Human Rights Law, Oxford University Press, 2013, s. 554.

185 Wet, s. 555.

186 Questions relating to the Obligation to Prosecute or Extradite (Belgium v. Senegal), Judgment, I.C.J. Reports 2012, s. 449-450.

187 Case Concerning East Timor (Portugal v. Australia), Judgment, 30 June 1995, I.C.J. Reports 1995. 
Statüsü'nün 36/2. maddesi uyarınca UAD'nin yarg1 yetkisini kabul etmesine rağmen, Endonezya bunu kabul etmemiş ve bu nedenle de mahkemenin yalnızca devletlerin rıza gösterdiği durumlarda yargılama yetkisine sahip olduğunu belirten UAD Statüsü nedeniyle kıta sahanlığına ilişkin antlaşmanın hukuka uygunluğuna dair bir karar verilememiştir. UAD, bu sonuca varırken, self-determinasyon hakkının erga omnes statüsünü ve özellikle Doğu Timor halkının self-determinasyon hakkını kabul etmiştir. ${ }^{188}$ UAD, yine de ileri sürülen yükümlülüklerin niteliğine bakılmaksızın, yalnızca yargı yetkisine rıza gösteren bir devletin davranışının hukuka uygunluğuna hükmedebileceğinin altını çizmiştir. Böylece UAD, bir hakkın erga omnes statüsünün devletleri kendi yarg1 yetkisini kabul etmeye zorlamadığını açıkça ortaya koymuştur. ${ }^{189}$ Bununla birlikte, UAD'nin kararından yola çıkarak söylenebilir ki, Endonezya UAD'nin yargı yetkisini kabul etmiş olsaydı, Portekiz Endonezya'ya karşı Doğu Timor halkının self-determinasyon hakkını ileri sürebilirdi. Zira Portekiz, Doğu Timor üzerinde de facto veya de jure hükmetme hakkına sahip olmasa da self-determinasyon hakkının erga omnes karakteri temelinde Doğu Timor halkının bu hakkının korunmasında "yasal bir çıkara" sahip olacaktı.

Uluslararası insan hakları hukukun, uluslararası örf ve âdet hukuku üzerinden erga omnes statüsü kazandığını ileri sürerken dayanılabilecek sağlam bir içtihat da Barcelona Traction davası sonucunda ortaya çıkmıştır. ${ }^{190}$ UAD tarafindan karara bağlanan Barcelona Traction davasında davacı Belçika ve davalı İspanya ihtilaf halinde olmuştur. Dava temel olarak Kanada kanunlarına göre kurulmuş ve İspanya'da faaliyet gösteren Barcelona Traction Şirketi'ne İspanya tarafından el konulması üzerine, şirketin Belçika vatandaşı olan hissedarları adına Belçika hükümetinin el koyma nedeniyle oluşan zararın diplomatik himaye temelinde tazmin talebine yöneliktir. Mahkemeye göre diplomatik himaye gerektiren yükümlülükler, yabancının vatandaş1 olduğu devlete karşı yerine getirilmesi gereken yükümlülükler olup, her devlet açısından uyulması gereken, yani erga omnes yükümlülükler değildir. Ancak diğer taraftan, soykırım ve saldırının yasaklanması veya kölelik ve ırkçılığın yasaklanması gibi temel insan hakları ile ilgili ilke ve kurallar erga omnes

188 Self-determinasyonun bir ilke mi yoksa hak mı olduğuna dair detaylı bir tartışma için bkz. Şahin Eray Kırdım/Atahan Demirkol, "San Francisco Konferansı Görüşmeleri ve Birleşmiş Milletler Kararları Işıı̆ında Self-Determinasyon Kavramının İncelenmesi”, 2021, 25(1), Ankara Hacı Bayram Veli Üniversitesi Hukuk Fakültesi Dergisi, s. 389-430.

189 Case Concerning East Timor, s. 101-102.

190 Barcelona Traction, Light \& Power Co., Ltd. (BeIg. v. Sp.), 1970 I.C.J. 3 (Second Phase) (Judgment of Feb. 5). 
yükümlülük doğurmaktadır. ${ }^{191}$ UAD’nin daha güncel kararları da bu argümanı desteklemektedir. Örneğin Diallo davasında Divan, insanlık dışı ve onur kırıcı muamelelerin yasaklanmasına ilişkin kurallar hakkında açıkça erga omnes nitelemesi yapmamasına rağmen, bu kuralları bünyesine alan uluslararas antlaşmaların tarafi olmasa bile her devlet açısından bağlayıcı olduğunu kabul etmiştir. ${ }^{192}$

UAD'nin Barcelona Traction kararında ${ }^{193}$ ifade ettiği gibi irkçıllı̆ga dayalı ayrımcılıktan ve kölelikten korunma ile soykırım yasağ 1 gibi temel insan hakları erga omnes niteliğine sahip olarak kabul edilmektedir. ${ }^{194}$ Dolayısıyla, Sinclair'in de belirttiği üzere buradan yapılabilecek yorum, temel insan hakları olarak nitelenecek hakların erga omnes niteliğini kazanabilecekken, temel insan hakları dışında kalanların erga omnes olarak değerlendirilemeyeceğidir. ${ }^{195}$ Ancak bu hususta temel insan haklarının kapsamı UAD tarafından net olarak belirlenmemiş dolayısıyla tartışmaya açık bırakılmıştır. ${ }^{196}$ Ayrıca belirtilmelidir ki Barcelona Traction davasında UAD, "insan hakları" kavramı yerine "insanın temel hakları (the basic rights of the human person)" ifadesini kullanmayı tercih etmiştir. ${ }^{197}$ Buradan hareketle Meron, Divan'ın olağan insan hakları ile temel insan hakları arasında bilinçli bir ayrım yapmış olabileceğini ileri sürmüştür. ${ }^{198}$ Kanaatimizce de temel insan hakları kavramının kapsamı, yaşam hakkı gibi yokluğu halinde insan hayatını doğrudan tehdit edecek haklar olarak anlaşılmalıdır. Bu itibarla, temel insan hakları kavramı kısıtlı bir çekirdek haklar kategorisine işaret etmektedir.

Uluslararası örf ve âdet hukukunun insan hakları hukukunun kaynağı

191 Barcelona Traction, s. 32.

192 Case Concerning Ahmadou Sadio Diallo, (Republic of Guinea v. Democratic Republic of The Congo), Judgment, ICJ Reports, 30 November 2010, s. 671.

193 Barcelona Traction davasının uluslararası hukuk kuralları açısından ortaya çıkardığı etkileri detaylı şekilde ele alan bir çalışma için bkz. Yasin Söyler, "Barcelona Traction Davası ve Uluslararas1 Hukuka Etkisi”, 2015, 19(3), Ankara Hac1 Bayram Veli Üniversitesi Hukuk Fakültesi Dergisi, s. 207-248.

194 Barcelona Traction, s. 32.

195 Ian Sinclair, The Vienna Convention on the Law of treaties, 2. Bask1, Manchester University Press, 1984, s. 213.

196 Kemal Başlar, "Uluslararası Hukukta Erga Omnes Kavramı”, 2002, 22(2), Milletleraras1 Hukuk ve Milletlerarası Özel Hukuk Bülteni, Prof. Dr. Ergin Nomer’e Armağan, s. 92.

197 Barcelona Traction, s. 32.

198 Theodor Meron, Human Rights Law-Making in the United Nations, Clarendon, 1986, s. 185-186. 
olarak görülmesi durumunda, Barcelona Traction kararında ifade edildiği gibi ${ }^{199}$ uluslararası toplumun tümüne yönelik yükümlülüklerin erga omnes niteliğini haiz olması sebebiyle, insan hakları hukuku da erga omnes niteliğine kavuşmaktadır. ${ }^{200}$ Ancak her ne kadar örf ve âdetin uluslararası insan hakları hukukunu erga omnes niteliğine kavuşturduğu söylense de bu örf ve âdet kurallarını ulusal hukukunda uygulamayan devletler de vardır. Örneğin ABD'de yerel mahkemeler örf ve âdete dayalı uluslararası insan hakları hukukunu bir ulusal hukuk kuralı olarak görmemektedirler. ${ }^{201}$ Zira ABD'de uluslararası insan hakları hukukunun mahkemelerce uygulanması tartışmalı bir konudur. ${ }^{202}$ Çok taraflı uluslararası sözleşmeler, örf ve âdete dayalı uluslararası insan hakları hukukunun temel kaynağı olarak kabul edilirken, bu yolla oluşan uluslararası insan hakları hukuku ABD'de federal hukukun bir kaynağ olarak görülmemektedir. ${ }^{203}$

Uluslararası örf ve âdet hukukundan kaynaklanan şekilde uluslararası insan hakları hukuku kurallarının erga omnes niteliği kazanması görüşü, bir başka tartışmaya daha yol açmaktadır. Önceki bölümlerde ifade edildiği üzere örf ve âdet hukuku tüm devletleri bağlayıcı olmakla birlikte tek istisnası 1srarlı itirazc1 (persistent objector) kuralıdır. Erga omnes niteliğini kazanmamış uluslararası insan hakları hukuku kurallarına 1srarlı itirazcı olunması önünde herhangi bir engel olmadığı düşünülmektedir. Ancak erga omnes haklara ilişkin doktrinde tartışmalı bir durum bulunmaktadır. Örneğin Byers'in görüşüne göre erga omnes niteliğini haiz bir kurala karşı 1srarlı itirazcı olunamayacağına dair bir yaklaşım doğru değildir. ${ }^{204}$ Dolayısıyla bu görüşe göre 1srarlı itirazc1 devletler, bir kuralın erga omnes niteliğinden etkilenmezler. ${ }^{205}$ Bunun tam karşıtı olan görüş ise, Güney Afrika örneğinde ortaya çıkmaktadır. Güney Afrika, ırk ayrımcılığı (racial discrimination) yasağına karşı 1srarlı itirazcı

199 Barcelona Traction, s. 32.

200 Thirlway, "Human Rights in Customary Law", s. 499.

201 Gordan A. Christenson, "Customary International Human Rights Law in Domestic Court Decisions", 1995, 25, Georgia Journal of International and Comparative Law, s. 226.

202 David F. Klein, "A Theory for the Application of the Customary International Law of Human Rights by Domestic Courts", 1988, 13, Yale Journal of International Law 13, s. 332.

203 Curtis A. Bradley/Jack L. III Goldsmith, "The Current Illegitimacy of International Human Rights Litigation", 1997, 66, Fordham Law Review, s. 340; Curtis A. Bradley/Jack L. Goldsmith, "Federal Courts and the Incorporation of International Law", 1997, 111, Harvard Law Review, s. 2261-2262.

204 Byers, s. 198.

205 Byers, s. 198. 
olduğunu dile getirmiştir. Ancak bu itiraz genel kabulle reddedilmiştir. Ret gerekçesi ise dikkat çekicidir, zira ırk ayrımcılığı sıradan bir uluslararası örf ve âdet kuralı olmayıp emredici kural (peremptory law) niteliğindedir. ${ }^{206} \mathrm{Bir}$ kuralın emredici kural olması ise o kuralın tüm devletler tarafindan olmasa da çoğunluğunun kabulüne bağlıdır. ${ }^{207} \mathrm{Bu}$ tür kurallar ise, genel kabule göre 1srarl1 itirazcılığa izin vermemektedir. ${ }^{208}$ Ayrıca Uluslararası Hukuk Komisyonu da erga omnes niteliğindeki kurallara karşı 1srarlı itirazcı olunamayacağı görüşünü ifade etmektedir. ${ }^{209} \mathrm{Bu}$ konudaki kanaatimiz, erga omnes niteliği kazanmış uluslararası insan hakları kurallarına karşı 1srarlı itirazc1 olunamayacağ1 yönündedir. Zira 1srarlı itirazın daha önceki bölümlerde anlatıldığ 1 üzere bir kuralın oluşum aşamasında yapılması gerektiği bilinmektedir. Bu itibarla, bu kural erga omnes niteliğini kazanmış ise, o kuralın hukuk düzeninde ipso facto meydana geldiği ve artık itiraz şansı kalmadığ 1 kabul edilmelidir. Ayrıca erga omnes niteliği bir anlamda ilgili kurala evrensel olma karakteri vermekle onu diğer kurallardan farklılaştırmaktayken bu kurala karş1 1srarcı itirazc1 olabilmek erga omnes niteliğin ruhuna da aykırı olacaktır.

Uluslararası örf ve âdet hukukunun, uluslararası insan hakları hukukuna erga omnes niteliği sağladığı daha önce ifade edilen doktrinde ve içtihat hukukunda sabittir. Bu bağlamda uluslararası insan hakları hukukunun gelişiminde örf ve âdetin etkisi, onun evrensel anlamda uygulanabilecek, tüm devletlere karşı ileri sürülebilecek ve bağlayıcı olacak bir kurallar silsilesi haline gelmesine katkı sağlamaktır. Her ne kadar örf ve âdetin uluslararası insan hakları hukukunu erga omnes niteliğine kavuşturduğu ifade edilse de ABD örneğinde görüldüğü gibi ulusal mahkemelerinde bu örf ve âdet hukuku kurallarını insan hakları hukuku olarak görmeyen devletler de olabilmektedir. $\mathrm{Bu}$ itibarla uluslararası örf ve âdetin, insan hakları hukukunun evrenselliğine kayıtsız şartsız bir katkı sağladığı ifadesi de yanlış olacaktır.

206 Jure Vidmar, "Norm Conflicts and Hierarchy in International Law: Towards a Vertical International Legal System?", in Erika De Wet/Jure Vidmar (eds.), Hierarchy In International Law: The Place Of Human Rights, Oxford University Press, 2012, s. 26.

207 Erika De Wet, "Invoking Obligations Erga Omnes in the Twenty-First Century: Progressive Developments since Barcelona Traction", 2013, 38(1), South African Yearbook of International Law, s. 8.

208 Vidmar, s. 26.

209 Report of the International Law Commission, Sixty- seventh session, 4 May-5 June and 6 July-7 August 2015, UN Doc. A/70/10, Advance Unedited Version, 24 August 2015, s. 40, para. 94. 


\section{Evrensel Bir İnsan Hakları Hukuku: Eleştirel Bir Yaklaşım}

Uluslararası örf ve âdet hukuku ile uluslararası insan hakları hukuku arasındaki ilişkiye dair üçüncü tartışma ise, örf ve âdet hukuku sebebiyle evrensellik kazanan insan haklarının batılı devletlerin egemen bakış açısıyla $\mathrm{m} 1$ dikte edildiğine ilişkindir. Örf ve âdetin uluslararası insan hakları hukukuna katkısı doktrinde açıkça görülmektedir. Uluslararası örf ve âdet hukuku, sözleşmeler sistemi ile kıyaslandığında, bu kuralların imzacı olmayan devletleri de bağlayacak nitelikte genişletilmesine bir vesile olabilmektedir. $\mathrm{Bu}$ açıdan da insan hakları hukukunun ve küresel insan hakları anlayışının gelişmesine katkı sağlayabilmektedir. Ancak diğer bir yandan, bu düşünce kültürel ve bölgesel değişiklikleri göz ardı etmektedir. İnsan hakları algısı her ne kadar küresel ve evrensel olsa da kültürel farklılıklar değişik insan hakları gruplarının da uygulanmasını gerektirebilir. Bu bağlamda örf ve âdet hukukunun insan hakları bağlamında bölgesel hassasiyetleri de barındıracak şekilde bir katılıma izin vermesi önemlidir.

Genel olarak kabul gördüğg̈ ve Henkin tarafından da ifade edildiği gibi, insan hakları dünyanın her yerindeki insanlara herhangi bir zamanda atfedilebilecek, bir anlamda zamanı ve mekânı olmadan ileri sürülebilecek haklardır. ${ }^{210}$ İnsan hakları kurallarının evrensel niteliği, çeşitli uluslararası belgelerde vurgulanmıştır. Örneğin 1993 tarihli Viyana Deklarasyonu ve Eylem Planı'nda ifade edilen şekliyle insan haklarının ve özgürlüklerinin evrenselliği sorgulanabilir değildir. ${ }^{211} \mathrm{Bu}$ itibarla Henkin, İHEB ve BM Şart1 gibi insan haklarına ilişkin hükümler içeren belgelerin devletlerin çoğunluğu tarafindan kabul edilmiş olması, birçok devletin anayasasında insan haklarına ilişkin ifadelerin bulunması ve tüm devletleri bağlayan örf ve âdete dayalı uluslararası insan hakları hukuku kurallarının oluşması sebebiyle insan haklarının bir şekilde evrensellik niteliğini haiz olduğunu kabul etmektedir. ${ }^{212}$ Yine de evrensel olan uluslararası insan hakları hukuku rejimi, uluslararası ölçekte kabul görmüş insan hakları kurallarının ulusal düzeyde uygulanmasını gerektirir. ${ }^{213}$ Ancak bu gerçeklik, ABD gibi güçlü Birinci Dünya ülkelerinin

210 Louis Henkin, "The Universality of the Concept of Human Rights", 1989, 506(1), The ANNALS of the American Academy of Political and Social Science, s. 11.

211 UN General Assembly, Vienna Declaration and Programme of Action, 12 July 1993, A/ CONF.157/23.

212 Henkin, The Universality of the Concept of Human Rights, s. 13.

213 Jack Donnelly, “The Relative Universality of Human Rights", 2007, 29(2), Human Rights Quarterly, s. 283. 
iç hukuklarında örf ve âdetten doğan insan haklarını uygulamakta çekince gösterdikleri durumlarda küresel bir baskı yaşamadıkları göz önünde bulundurulduğunda, evrensel bir uluslararası insan hakları hukuku algısının yerleşmesiyle çelişki oluşturmaktadır.

Örf ve âdet hukukuna dayalı insan haklarının batılı bir hegemonya aracı haline dönüşüp dönüşmediği sorusu, TWAIL akademisyenlerinin uluslararas1 hukuk için dile getirdikleri argüman üzerinden yorumlanabilir. Örneğin Mutua, uluslararası insan hakları hukukunun küstah bir Avrupa merkezcilik örneği olduğunu dile getirmektedir. ${ }^{214}$ Yine Kırdım'a göre, UAD'nin Nicaragua davasındaki "bir devlet için, o devlet tarafindan antlaşma yoluyla veya başka bir şekilde kabul edilmiş olanlar dışında, uluslararası hukukta hiçbir kural yoktur ... ve bu ilke istisnasız tüm devletler için geçerlidir" ifadesi, modern uluslararası hukukta sahte bir katılımcılık algisının yaratılmasina neden olmaktadır. ${ }^{215}$ Zira özellikle uluslararası örf ve âdet hukukunun ortaya çıkışında bakılacak genel devlet uygulaması ve opinio juris Üçüncü Dünya ülkeleri arasından değil, öncelikli olarak Birinci Dünya devletleri arasından seçilecektir. ${ }^{216} \mathrm{Bu}$ durumda uluslararası hukukun ve onun da bir alt dalı olan uluslararası insan hakları hukukunun gerçekten dünya devletlerinin kaçını temsil edeceği konusunda çok da iyimser davranılamayacaktır.

$\mathrm{Bu}$ itibarla, modern uluslararası insan hakları hukukunun temel belgelerinden biri olarak kabul edilen İHEB dahi Üçüncü Dünyacı bakış açılarından eleştirilmiştir. Örneğin Shah'a göre, İHEB emperyalist ve kolonyalist bir alt yap1 üzerine oluşturulmuş, böylece özgürlük ve hak kavramlarını da batılı bir bakış açısından tanımlamıştır. ${ }^{217}$ Benzer şekilde Mutua uluslararası insan hakları hukukunun Avrupa merkezcilik düşüncesinin yaygınlaştırılması üzerine inşa edilmiş olduğunu ifade ederken, Chimni ise uluslararası insan haklarının Üçüncü Dünya devletlerinin neo-liberal politikaları uygulaması yönündeki baskıyla eş zamanlı olarak manipüle edildiklerini vurgulamaktadır. ${ }^{218}$ Zabunoğlu ve Sönmez de keskin bir şekilde

214 Mutua, What Is TWAIL?, s. 36-37.

215 Kirdim, s. 142.

216 Kirdım, s. 151.

217 Jeena Shah, "UDHR: Our North Star for Global Social Justice or an Imperial and SettlerColonial Tool to Limit Our Conception of Freedom", 2018, 31, Pace International Law Review, s. 569.

218 Makau Mutua, "Critical Race Theory and International Law: The View of an InsiderOutsider", 2000, 45, Villanova Law Review, s. 850; B. S. Chimni, “Third World Approaches 
uluslararası insan haklarının Avrupa merkezciliğinin aşikâr olduğunu ileri sürmektedir. ${ }^{219}$ Bunun göstergesi olarak Zabunoğlu ve Sönmez, Mutua ile benzer şekilde İHEB' in BM Genel Kurulu Kararı olması sebebiyle bu belgenin ortaya çıkartılmasında yalnızca BM Genel Kurulu üyesi olma şansına sahip Batı devletlerinin söz sahibi olduğunu dile getirmektedir. ${ }^{220} \mathrm{Bu}$ görüşler doğrultusunda denilebilir ki doktrindeki bir yaklaşım, uluslararası insan hakları hukukunu Batı veya Birinci Dünya devletlerinin hegemonyası altında oluşturulmuş bir değerler sistemi olarak görmektedir. Zira bu görüşe göre, Robbins'in de ifade ettiği gibi uluslararası insan hakları hukukunda güçlü iki rejim olan Amerikan ve Avrupa sistemleri bu alanda hâkim konumda kalmaya devam ederlerse, batılı olmayan insan hakları tehlike altında olacaktır. ${ }^{221}$

TWAIL, Badaru'ya göre uluslararası insan haklarını incelemekte birkaç temel katkı sağlamaktadır. ${ }^{222}$ Bunlardan ilki, TWAIL'in uluslararası insan hakları hukukunu çözümlerken benimsediği tarihsel bakış ve disiplinler arası yaklaşımdır. Zira Üçüncü Dünya ülkelerinde bugün yaşanan insan hakları ihlalleri incelenirken tarihsel perspektiften de yararlanılmalıdır. İkincisi, bu yaklaşım uluslararası hukukun uygulanmasındaki çifte standardı ortaya koymaktadır. Örneğin, Badaru’ya göre insan haklarının uygulanmasının her zaman ön planda tuttuğunu iddia eden Bat1, uluslararası ticaret hukukunun insan hakları hukukunu ihlal ettiği durumlarda gözlerini kapatmaktadır. ${ }^{223}$ Üçüncüsü, TWAIL insan hakları değerlerinin ve kurallarının evrensel niteliği kazanmasına ilişkin bir sorgulamaya imkân vermektedir. ${ }^{224}$ Son olarak TWAIL, insan hakları kavramının Üçüncü Dünya'nın tüm sorunlarına çözüm

to International Law: A Manifesto", 2006, 8(1), International Community Law Review, s. 3; B. S. Chimni, International Law and World Order: A Critique of Contemporary Approaches, 2. Bask1, Cambridge University Press, 2017, s. 291.

219 Hamdi Gökçe Zabunoğlu/Esma Yağmur Sönmez, "Uluslararası İnsan Hakları Hukukunda Üçüncü Dünya Yaklaşımları”, 2021, 12(1), İnönü Üniversitesi Hukuk Fakültesi Dergisi, s. 262.

220 Zabunoğlu/Sönmez, 263; Makau Mutua, “The Ideology of Human Rights”, 1996, 36(3), Virginia Journal of International Law, s. 589.

221 Melissa Robbins, "Powerful States, Customary Law and the Erosion of Human Rights through Regional Enforcement", 2004, 35, California Western International Law Journal, s. 301-302.

222 Opeoluwa Adetoro Badaru, "Examining the Utility of Third World Approaches to International Law for International Human Rights Law", 2008, 10(4), International Community Law Review, s. 379-387.

223 Badaru, s. 383.

224 Badaru, s. 384. 
olacak bir araç olmadığını anlamamıza yardımcı olmaktadır. Nitekim Üçüncü Dünya'nın sorunlarının çözülebilmesi için insan hakları ihlallerinin yanında ekonomik ve siyasal araçlara da ihtiyaç vardır. ${ }^{225}$

TWAIL'in uluslararası insan haklarına yönelik bu katkılarından hareketle bakıldığında, Ramina'nın aktarımına göre Rémi Bachand da TWAIL'in insan haklarına ilişkin üç eleştiri noktası olduğunu ifade etmektedir. ${ }^{226}$ İlk eleştiri, insan haklarının köken olarak Avrupa toplumlarına ait olmasa da bugünkü evrensel uluslararası insan hakları anlayışının tamamen Avrupa merkezci olduğuna yöneliktir. İkinci eleştiri, insan haklarının Avrupa tarafından Üçüncü Dünya devletlerinin "vahşi ve yabani” kültürlerinden arınmalarını sağlayarak onları medenileştirmek için kullanılan kolonyal ve emperyalist müdahaleler olduğuna ilişkindir. Son eleştiri ise, Avrupa merkezli insan haklarının liberal demokrasileri teşvik etmek suretiyle Üçüncü Dünyanın emperyalizm ve neo-kolonyalizm ile mücadelesini engellemesi üzerinedir. ${ }^{227} \mathrm{Bu}$ bağlamda değerlendirildiğinde TWAIL bakış açısından uluslararası insan hakları hukuku, Üçüncü Dünya'nın ihtiyaçlarını karşılayacak nitelikte görülmemektedir. ${ }^{228}$

Mutua, ürettiği üçlü metafor üzerinden insan hakları yaklaşımını eleştiriye tabi tutmaktadır. Barbarlar-kurbanlar-kurtarıcılar (BKK) olarak tasvir edilen bu üçlü metafor, barbaları bir tarafa koyarken, karşı tarafta da kurbanlar ve kurtarıcıları konumlandırmaktadır. ${ }^{229} \mathrm{Bu}$ metafor içerisinde barbarlar devleti temsil etmektedir. Bu itibarla devletler sivil topluma bask1 yarattığı müddetçe barbarlaşırlar. Kurbanlar, barbar olan devlet tarafından zorbalığa uğramış insanlığı ifade etmektedir. Üçüncü unsur olan kurtarıcılar ise BM, batılı devletler ve batılı yardım kuruluşlarıdır. BKK metaforu üzerinden değerlendirmesini yapan Mutua, insan hakları kurallarının Avrupa merkezli kolonyalizmin bir devamı niteliğinde olduğunu ve bu sebeple de bu kuralların evrensellik iddiasının zayıfladığını ifade etmektedir. Mutua, bir diğer taraftan bu metaforun batılı kültürlerin batılı olmayan kültürler üzerinde kurduğu hegemonyaya ve onları batının bir prototipi haline çevirmelerine yönelik bir ön kabulü olduğunu iddia etmektedir. Son olarak Mutua, insan

225 Badaru, s. 384.

226 Larissa Ramina, "TWAIL - 'Third World Approaches to International Law' and Human Rights: Some Considerations”, 2018, 5(1), Revista de Investigações Constitucionais, s. 264,

227 Ramina, s. 264-65.

228 Ramina, s. 271.

229 Makau Mutua, "Savages, Victims, and Saviors: The Metaphor of Human Rights", 2001, 42(1), Harvard International Law Journal, s. 201. 
hakları hareketinin kültürler arası meşruiyet kazanmasını engelleyecek bir şekilde küstah bir dile sahip olduğunu ileri sürmektedir. ${ }^{230}$

Buradan hareketle söylenebilir ki Henkin'in tespitine göre genellikle Asya ülkelerinden gelmekte olan insan haklarının evrenselliğine yönelik itirazların en büyük sebebi kültüreldir, ki bizatihi Henkin bu itirazların yerinde olmadığını ifade etmektedir. ${ }^{231}$ Zira ona göre Üçüncü Dünya devletlerinin insan haklarına olan karşıtllı̆̆ bu kurallara değil, BM politikalarına yöneliktir. ${ }^{232}$ TWAIL açısından da göz önüne alındığında bu konunun haklılık payı vardır. Uluslararası hukuk altında hegemon güçlerin sömürüsüne tabi tutulmuş olan Üçüncü Dünya devletlerinin, uluslararası insan hakları hukukunun da evrensel niteliği haiz olmasına tarihsel tecrübelerinden dolayı tepki gösterdikleri düşünülebilir. Uluslararası örf ve âdet hukuku, uluslararası insan hakları hukukuna evrensel, bir diğer ifadeyle erga omnes niteliği kazandırırken Üçüncü Dünya devletleri uluslararası insan hakları hukukunun bu niteliğini eleştiriye tâbi tutmaktadır. Evrensel bir insan hakları hukuku, bağlayıcı kuralların erga omnes niteliğini kazanması anlamında mümkün görünmektedir. Ancak evrensel insan hakları hukukunun batılı olmayan insan hakları kurallarını da dikkate alması, Üçüncü Dünya devletlerinin de bu kurallara olan tepkisini azaltacaktır. Bu itibarla, evrensel bir insan hakları hukuku rejiminin kurulması ancak Birinci Dünya ile Üçüncü Dünya arasındaki eşitsizliğin giderilmesine bağlı olacaktır.

\section{DEĞERLENDİRME VE SONUÇ}

Modern anlamda insan hakları, insanları siyasal iktidarın, bir diğer deyişle devletin zulmünden korumak amacını taşımaktadır. Bu anlamda insan hakları, insan olmaktan kaynaklanan ve doğuştan kazanılan birtakım haklar olup, bu hakların tarihsel karşıtları devletler olmuştur. Zira ulusal insan hakları belgelerinin tarihsel gelişim sürecine bakıldığında, muhtemel ihlalci konumundaki öznenin daima devletler olduğu görülecektir. Örneğin keyfi tutuklamanın veya ev sahibinin rızası olmadan askerlerin evlerde konaklamasının yasaklanması, kişi hürriyeti ve mülkiyet hakkının devlete karşı korunması amacını taşımaktadır. Bugün gelinen noktada ise, sürekli küçülmekte olan küresel bir topluluğun üyeleri olarak her insan, vatandaş1

\footnotetext{
${ }^{230}$ Mutua, Savages, Victims, and Saviors: The Metaphor of Human Rights, s. 204-206.

231 Henkin, "The Universality of the Concept of Human Rights", s. 14; Christina M. Cerna, "Universality of Human Rights and Cultural Diversity: Implementation of Human Rights in Different Socio-Cultural Contexts", 1994, 16(4), Human Rights Quarterly, s. 744.

${ }^{232}$ Henkin, "The Universality of the Concept of Human Rights", s. 14.
} 
olduğu ülke devletine karş1 -yükümlülükler yanında- birtakım haklara sahip olup, dahası bu hakların korunması yükümlülüğü de devlete aittir.

Devletlerin kendi vatandaşlarının insan haklarını korumak konusunda ülkeden ülkeye değişen birtakım yükümlülüklere sahip oldukları aşikârdır. Ancak uluslararası toplum üyeleri, insan hakları özelinde söylem düzeyini aşarak eylem düzeyinde karşıllk bulan bir koruma yükümlülüğüne de sahiptirler. İHEB'te ifadesini bulan şekliyle devletler, “insan haklarının ve temel özgürlüklerin evrensel olarak saygı görmesi ve gözetilmesini sağlamayı taahhüt [etmişlerdir]." ${ }^{233}$ Ancak Goodale'nin de belirttiği üzere, devletlerin normatif olarak ifade edilmiş olan insan haklarını korumak için herhangi bir yükümlülük altına girmeden, yalnızca insan hakları idealinin fikir bayraktarlığını yapması anlamsızdır. ${ }^{234}$

Eldeki çalışma, uluslararası örf ve âdet hukukunun normatif insan haklarının korunması açısından evrensel bir koruma mekanizması oluşturmaya imkân sağladığını göstermektedir. Uluslararası örf ve âdet hukuku, kural olarak tüm devletler üzerinde bağlayıcı normlar içeren bir uluslararası hukuk kaynağıdır. Uluslararası örf ve âdet yoluyla bir hukuk normu oluşması için, devletlerin genel çoğunluğunun belirli bir yönde davranması ve bu davranışın da hukuki bir yükümlülük nedeniyle gerçekleştiriliyor olduğu inancı gereklidir. Dahası, her ne kadar uluslararası hukuka hâkim olan ilkelerden biri devletlerin egemen eşitliği olsa ve bu ilke uyarınca uluslararası hukukta devletleri bağlayıcı kurallar yine bizatihi devletlerin rızasına dayalı olarak oluşmakta ise de uluslararası örf ve âdet hukukunun işleyiş mantığı gereğince -bölgesel nitelikli olmayan kurallar haricinde- devletlerin açık rızalarına gerek yoktur. Bu anlamda, bir uluslararası örf ve âdet hukuku kuralı, söz konusu kuralın oluşumu aşamasında kurala 1srarlı olarak itiraz etmeyen tüm devletler açısından bağlayıcı olacaktır. Dolayısıyla uluslararası örf ve âdet hukuku, 1srarlı itiraz kuralı istisna olmakla beraber evrensel olarak bağlayıcı kurallar üretmektedir.

Doğal hukuk anlayışına dayanan insan hakları tüm insanlığın ortak değerlerinin korunmasını amaçlamaktadır. Uluslararası insan haklarının erga omnes niteliği hem devlet uygulamalarında hem de içtihat hukukunda kabul

233 UN General Assembly, Universal Declaration of Human Rights, 10 December 1948, 217 A (III), preamble.

234 Mark Goodale, "Introduction Locating Rights, Envisioning Law Between the Global and the Local", in Mark Goodale/Sally Engle Merry (eds.), The Practice of Human Rights: Tracking Law between the Global and the Local, Cambridge University Press, 2007, s. 10. 
edilmektedir. Dahası insan hakları, uluslararası insan hakları belgelerinde normatif hükümlerle korunmuyor olsa bile, uluslararası örf ve âdet hukukunca tanınan bazı temel haklar vardır ki bunlar uluslararası toplumun tümüne yönelik erga omnes yükümlülükler içeren bir niteliği haizdir. Bu nitelik, uluslararası insan hakları ile uluslararası örf ve âdet hukukunun "tüm devletlerin meselesi" ortak paydasında buluşmasıyla desteklenmektedir.

Uluslararası örf ve âdet hukukunun en azından bazı insan hakları ihlallerini tüm devletlerin korumakla yükümlü saydığı bir kapsama dahil etmesi, insan haklarına evrensel bir nitelik kazandırmakta ise de bu durumun uygulamada önemli sayılabilecek ve insan haklarının evrenselliğini zedeleyici bir etkisinin olduğu da kabul edilmelidir. Zira TWAIL akademisyenlerinin de vurguladığ1 üzere, hangi devlet davranışlarının uluslararası örf ve âdet hukuku normu oluşturmakta olduğu veya oluşturduğunun tespiti açısından Birinci Dünya devletleri Üçüncü Dünya devletlerine nazaran çok daha avantajlıdır. Birinci Dünya devletleri uluslararası örgütlerde ve uluslararası ilişkilerdeki hegemon konumları sayesinde, seslerini daha fazla duyurabilmektedir. Dahası, bu seslerin yüksek desibeli Üçüncü Dünya devletlerinin seslerini bastırmaktadır. Dolayısıyla Birinci Dünya devletlerinin kendi bakış açılarından oluşturulan bir dizi hak, tüm devletlere evrensel insan hakları olarak tembih edilmektedir. Bu nedenle de bazı Üçüncü Dünya devletleri, bazı uluslararası insan haklarını kültürel nedenlerle eleştiriye tâbi tutabilmektedir.

Kanaatimizce insan haklarının evrensel düzeyde korunması, bunların erga omnes niteliğini kazanması ile mümkün görünmektedir. Buna karşın insan hakları hukukuna evrensel niteliği aşılanırken, batılı olmayan insan hakları kurallarının ya da insan haklarının batılı olmayan görünümlerinin de dikkate alınması, Üçüncü Dünya devletlerinin bu sürece katılımını ve insan haklarının evrensel düzeyde korunmasını arttıracaktır. Dolayısıyla, uluslararası örf ve âdet hukukunun insan haklarının evrensel düzeyde korunmasına yönelik olumlu katkısı açı olmakla beraber, batılı olmayan ülkelerin insan hakları normlarının oluşum sürecinde ikinci plana itilmesinin evrensel olması gereken insan haklarına yabancılaşılmasına yol açabileceği de akılda tutulmalıdır. 
Uluslararası İnsan Hakları Hukukunun Bir Kaynağı Olarak Uluslararası Örf ...

\section{KAYNAKÇA}

African Union, Protocol to the African Charter on Human and People's Rights on the Rights of Women in Africa, 11 July 2003.

Akehurst M, "Custom as a Source of International Law", 1976, 47(1), British Yearbook of International Law, s. 1-53.

Akkutay A İ, “İnsan Hakları Hukukunun Pozitivist Yönünü Oluşturan İlgili Uluslararası Antlaşmaların Feminist Yaklaşıma Etkisi”, 2017, Özel Sayı, Türkiye Barolar Birliği Dergisi, s. 14-42.

Alves J A L, "The Declaration of Human Rights in Postmodernity", 2000, 22, Human Rights Quarterly, s. 478-500.

Arsava A F, "Uluslararası Hukukta Güç ve Hukuk İlişkisi”, 2012, 3(10), TAAD, s. 351-380.

Austin J, Lectures on Jurisprudence, J. Murray, 1869.

Aybay R, İnsan Hakları Hukuku, 3. Bask1, İstanbul Bilgi Üniversitesi Yayınlar1, 2017.

Badaru OA, "Examining the Utility of Third World Approaches to International

Law for International Human Rights Law", 2008, 10(4), International Community Law Review, s. 379-387.

Barcelona Traction, Light \& Power Co., Ltd. (BeIg. v. Sp.), 1970 I.C.J. 3 (Second Phase) (Judgment of Feb. 5).

Barkin J S, "The Evolution of the Constitution of Sovereignty and the Emergence of Human Rights Norms", 1998, 27(2), Millennium, s. 229252.

Barna M, "Sosyal Devlet ve Eşitlik", 2001, 3, İzmir Barosu Dergisi, s. 107114.

Başlar K, "Uluslararası Hukukta Erga Omnes Kavramı", 2002, 22(2), Milletlerarası Hukuk ve Milletlerarası Özel Hukuk Bülteni, Prof. Dr. Ergin Nomer'e Armağan, s. 75-108.

Baxi U, The Future of Human Rights, Oxford University Press, 2007.

Bederman D J, "Acquiescence, Objection and the Death of Customary International Law", 2010, 21(1), Duke Journal of Comparative \& International Law, s. 31-45. 
Beitz C, "What Human Rights Mean”, 2003, 132(1), Daedalus, s. 36-46.

Beitz C, The Idea of Human Rights, Oxford University Press, 2011.

Bos M, A Methodology of International Law, North-Holland, 1984.

Boucher D, "The Recognition Theory of Rights, Customary International Law and Human Rights", 2011, 59(3), Political Studies, s. 753-771.

Bradley C A/Goldsmith J L, "The Current Illegitimacy of International Human Rights Litigation”, 1997, 66, Fordham Law Review, s. 319-369.

Bradley C A/Goldsmith J L, "Federal Courts and the Incorporation of International Law", 1997, 111, Harvard Law Review, s. 2260-2275.

Brownlie I, Principles of Public International Law, Clarendon Press, 1973.

Buergenthal T, "The Evolving International Human Rights System", 2006, 100(4), American Journal of International Law, s. 783-807.

Buergenthal T, "The Normative and Institutional Evolution of International Human Rights", 1997, 19(4), Human Rights Quarterly, s. 703-723.

Byers M, Custom, Power and the Power of Rules: International Relations and Customary International Law, Cambridge University Press, 1999.

Çalık T, "Birleşmiş Milletler İnsan Hakları Sözleşmeleri Kapsamında İnsan Haklarının Korunması", 2016, 24(1), Selçuk Üniversitesi Hukuk Fakültesi Dergisi, s. 69-120.

Case Concerning Ahmadou Sadio Diallo, (Republic of Guinea v. Democratic Republic of The Congo), Judgment, ICJ Reports, 30 November 2010.

Case Concerning East Timor (Portugal v. Australia), Judgment, 30 June 1995, I.C.J. Reports 1995.

Cassel D, "Does International Human Rights Law Make a Difference", 2001, 2, Chicago Journal of International Law, s. 121-135.

Çelebi H/Özdemir A M, "Uluslararası Hukukta Eleştirel Yaklaşımlar", 2010, 7(25), Uluslararası İlişkiler Dergisi, s. 69-90.

Cerna M, "Universality of Human Rights and Cultural Diversity: Implementation of Human Rights in Different Socio-Cultural Contexts", 1994, 16(4), Human Rights Quarterly, s. 740-752.

Chimni B S, "Customary International Law: A Third World Perspective", 2018, 112(1), American Journal of International Law, s. 1-46. 
Chimni B S, "Prolegomena to a Class Approach to International Law", 2010, 21(1), European Journal of International Law, s. 57-82.

Chimni B S, "Third World Approaches to International Law: A Manifesto", 2006, 8(1), International Community Law Review, s. 3-27.

Chimni B S, International Law and World Order: A Critique of Contemporary Approaches, 2. Bask1, Cambridge University Press, 2017.

Christenson G A, "Customary International Human Rights Law in Domestic Court Decisions", 1995, 25, Georgia Journal of International and Comparative Law, s. 225-254.

Committee on Formation of Customary (General) International Law, Final Report of the Committee, "Statement of Principles Applicable to the Formation of General Customary International Law", International Law Association, section 15, 2000, <http://www.law.umich.edu/ facultyhome/drwcasebook/Documents/ Documents/ILA\%20Report\%20 on $\% 20$ Formation $\% 20$ of $\% 20$ Customary\%20International $\% 20$ Law.pdf $>$ Erişim Tarihi 12.11.2020.

Council of Europe, European Convention for the Protection of Human Rights and Fundamental Freedoms, as amended by Protocols Nos. 11 and 14, 4 November 1950, ETS 5.

D’Amato A, "Human Rights as Part of Customary International Law: A Plea for Change of Paradigms", 1995, 25, Georgia Journal of International and Comparative Law, s. 47-98.

D'Amato A, "The Concept of Special Custom in International Law", 1969, 63(2), American Journal of International Law, s. 211-223.

D'Amato A, The Concept of Custom in International Law, Cornell University Press, 1971.

Dahlman C, "The Function of Opinio Juris in Customary International Law", 2012, 81(3), Nordic Journal of International Law, s. 327-339.

de Schutter O, International Human Rights Law: Cases, Materials, Commentary, Cambridge University Press, 2010.

de Wet E, "Invoking Obligations Erga Omnes in The Twenty-First Century: Progressive Developments Since Barcelona Traction", 2013, 38(1), South African Yearbook of International Law, s. 2-19. 
de Wet E, "Jus Cogens and Obligations Erga Omnes", in Dinah Shelton (ed.), The Oxford Handbook of International Human Rights Law, Oxford University Press, 2013, s. 540-560.

Demirci F, Meşru Devletin İnşası: Klasik Toplum Sözleşmesi Kuramlarında Birey-Devlet İlişkisi (Hobbes, Locke, Rousseau), 1. Bask1, Orion Akademi, 2021.

Dinstein Y, "The erga omnes Applicability of Human Rights", 1992, 30(1), Archiv des Völkerrechts, s. 16-21.

Doğan İ, İnsan Hakları Hukuku Ders Kitabı, 1. Baskı, Astana Yayınları, 2013.

Domingues v United States, merits, 2002 IACHR, Report No. 62/02, Case 12.285 .

Donnelly J, "Human Rights as Natural Rights", 1982, 4(2), Human Rights Quarterly, s. 391-405.

Donnelly J, "The Relative Universality of Human Rights", 2007, 29(2), Human Rights Quarterly, s. 281-306.

Donnelly J/Whelan D J, International Human Rights, 5. Bask1, Routledge, 2018.

Dumberry P, "Incoherent and Ineffective: The Concept of Persistent Objector Revisited", 2010, 59(3), International and Comparative Law Quarterly, s. $779-802$.

Elias O, "The Nature of the Subjective Element in Customary International Law", 1995, 44(3), The International and Comparative Law Quarterly, s. 501-520.

Erdoğan M, İnsan Hakları Teorisi ve Hukuku, 2. Bask1, Orion Kitabevi, 2011.

Evans T, "International Human Rights Law as Power/Knowledge", 2005, 27(3), Human Rights Quarterly, s. 1046-1068.

Fidler D, "Challenging the Classical Concept of Custom: Perspectives on the Future of Customary International Law", 1996, 39, German Yearbook of International Law, s. 198-248.

Forsythe D P, Human Rights in International Relations, Cambridge University Press, 2017.

Freeman M, Human Rights, John Wiley \& Sons, 2017. 
Galindo G R B/Yip C, "Customary International Law and the Third World: Do Not Step on the Grass", 2017, 16(2), Chinese Journal of International Law, s. 251-270.

Goldsmith J/Posner E, "A Theory of Customary International Law", 1999, 66(4), The University of Chicago Law Review, s. 1113-1177.

Goodale M, "Introduction Locating Rights, Envisioning Law Between the Global and the Local", in Mark Goodale/Sally Engle Merry (eds.), The Practice of Human Rights: Tracking Law between the Global and the Local, Cambridge University Press, 2007, s. 1-38.

Goodman R/Jinks D, "Measuring the Effects of Human Rights Treaties", 2003, 14(1), European Journal of International Law, s. 171-183.

Göçer M, "Uluslararası İnsan Hakları Andlaşmalarının Bağdaşmazlığı Sorunu ve Uluslararas1 Hukuk", 2001, 56(3), Ankara Üniversitesi SBF Dergisi, s. $47-70$.

Gözler K, İnsan Hakları Hukuku, 2. Baskı, Ekin Basım Yayın Dă̆ıtım, 2018.

Greer S, The European Convention on Human Rights: Achievements, Problems and Prospects, Cambridge University Press, 2006.

Guzman A, "Saving Customary International Law", 2005, 27(1), Michigan Journal of International Law, s. 115-176.

Haas H, International Human Rights: A Comprehensive Introduction, Routledge, 2014.

Hannum H, "The Status of the Universal Declaration of Human Rights in National and International Law", 1995, 25, Georgia Journal of International and Comparative Law, s. 287-397.

Hannum H, "The UDHR in National and International Law", 1998, 3(2), Health and Human Rights, s. 144-158.

Hathaway O A, "Do Human Rights Treaties Make a Difference?", 2002, 111(8), The Yale Law Journal s. 1935-2042.

Henkin L, "Human Rights and State Sovereignty", 1996, 25, Georgia Journal of International and Comparative Law, s. 31-45.

Henkin L, "The Universality of the Concept of Human Rights", 1989, 506(1), The ANNALS of the American Academy of Political and Social Science, s. $10-16$. 
Inter-American Commission on Human Rights (IACHR), American Declaration of the Rights and Duties of Man, 2 May 1948.

Inter-Science Research and Development Services (Pty) Ltd v Republica Popular Moçambique, per Margo J., 19802 SA 111 T, 125.

Joyner D, "Why I Stopped Believing in Customary International Law", 2018, 9(1), Asian Journal of International Law, s. 31-45.

Kapani M, İnsan Haklarının Uluslararası Boyutları, 2. Baskı, Bilgi Yayınevi, 1991.

Kapani M, Kamu Hürriyetleri, 7. Bask1, Yetkin Yayınları, 1993.

Kelly P, "The Twilight of Customary International Law", 1999, 40, Virginia Journal of International Law, s. 449-544.

Kelsen H, "Peace through Law", 1943, 2(1), Journal of Legal and Political Sociology, s. 52-67.

Kelsen H, Principles of International Law, 2. Bask1, Holt, Rinehart and Winston, 1966.

Kırdım Ş E, “TWAIL'i Anlamak: Uluslararası Hukuka Eleştirel Bir Yaklaşım”, 2021, 41(1), Public and Private International Law Bulletin, s.129-158.

Kırdım Ş E/Demirkol A, "San Francisco Konferans1 Görüşmeleri ve Birleşmiş Milletler Kararları Işı̆̆ında Self-Determinasyon Kavramının İncelenmesi”, 2021, 25(1), Ankara Hacı Bayram Veli Üniversitesi Hukuk Fakültesi Dergisi, s. 389-430.

Klein D F, "A Theory for the Application of the Customary International Law of Human Rights by Domestic Courts", 1988, 13, Yale Journal of International Law 13, s. 332-365.

Kolb R, "Selected Problems in the Theory of Customary International Law", Netherlands International Law Review, 2003, 50(2), s. 119-150.

Kunz J, "The Nature of Customary International Law", 1953, 47(4), American Journal of International Law, s. 662-669.

Kunz J L, "The United Nations Declaration of Human Rights", 1949, 43(2), American Journal of International Law, s. 316-323.

Lauren P G, The Evolution of International Human Rights: Visions Seen, 3. Bask1, University of Pennsylvania Press, 2011. 
Lepard B, "Introduction", in Brian D. Lepard (ed.), Reexamining Customary International Law, Cambridge University Press, 2017, s. 1-44.

Lillich R B, "The Growing Importance of Customary International Human Rights Law", 1995, 25, Georgia Journal of International and Comparative Law, s. 1-30.

Lutz E L/Sikkink K, "International Human Rights Law and Practice in Latin America", 2000, 54(3), International Organization, s. 633-659.

McClane JB , "How Late in the Emergence of a Norm of Customary International Law May a Persistent Objector Object", 1989, 13, ILSA Journal of International Law, s. 1-26.

Mendelson M, "The Subjective Element in Customary International Law", 1996, 66(1), British Yearbook of International Law, s. 177-208.

Meron T, "The Geneva Conventions as Customary Law", 1987, 81(2), American Journal of International Law, s. 348-370.

Meron T, Human Rights and Humanitarian Norms as Customary Law, Clarendon Press, 1989.

Meron T, Human Rights Law-Making in the United Nations, Clarendon, 1986.

Morsink J, The Universal Declaration of Human Rights: Origins, Drafting, and Intent, University of Pennsylvania Press, 1999.

Müllerson R, "On the Nature and Scope of Customary International Law", 1997, 2(1), Austrian Review of International and European Law Online, s. $341-360$.

Mumcu A/Küzeci E, İnsan Hakları \& Kamu Özgürlükleri: Kavramlar, Evrensel ve Ulusal Gelişimleri, Bugünkü Durumları, 3. Baskı, Savaş Yayınlar1, 2003.

Mutua M, "Critical Race Theory and International Law: The View of an Insider-Outsider", 2000, 45, Villanova Law Review, s. 841-854.

Mutua M, "Savages, Victims, and Saviors: The Metaphor of Human Rights", 2001, 42(1), Harvard International Law Journal, s. 201-245.

Mutua M, "The Ideology of Human Rights", 1996, 36(3), Virginia Journal of International Law, s. 589-657.

Mutua M, "What Is TWAIL?", 2000, 94, Proceedings of the ASIL Annual 
Meeting, s. 31-38.

Neumayer E, "Do International Human Rights Treaties Improve Respect for Human Rights?", 2005, 49(6), Journal of Conflict Resolution, s. 925953.

Pazarc1 H, Uluslararası Hukuk, 16. Bask1, Turhan Kitabevi, 2017.

Nevsun Resources Ltd. v. Araya, 2020 SCC 5 (February 28, 2020).

North Sea Continental Shelf cases (Federal Republic of Germany v Netherlands, Federal Republic of Germany v Denmark), merits, 1969 ICJ Rep. 3, para. 77; Military and Paramilitary Activities in and against Nicaragua (Nicaragua v United States of America), merits, 1986 ICJ Rep. 14.

Official Records of United Nations General Assembly, Fifty-sixth Session, 28 January 2002, UN Doc. A/RES/56/83.

Organization of African Unity (OAU), African Charter on Human and Peoples' Rights, 27 June 1981, CAB/LEG/67/3 rev. 5, 21 I.L.M. 58 (1982).

Organization of African Unity (OAU), African Charter on the Rights and Welfare of the Child, 11 July 1990, CAB/LEG/24.9/49 (1990).

Organization of African Unity (OAU), Convention Governing the Specific Aspects of Refugee Problems in Africa, 10 September 1969, 1001 U.N.T.S. 45.

Organization of American States (OAS), Additional Protocol to the American Convention on Human Rights in the Area of Economic, Social and Cultural Rights ("Protocol of San Salvador"), 16 November 1999, A-52.

Organization of American States (OAS), American Convention on Human Rights, "Pact of San Jose", Costa Rica, 22 November 1969.

Organization of American States (OAS), American Convention on Human Rights, "Pact of San Jose", Costa Rica, 22 November 1969.

Organization of American States (OAS), Charter of the Organisation of American States, 30 April 1948.

Organization of American States (OAS), Inter-American Convention to Prevent and Punish Torture, 9 December 1985, OAS Treaty Series, No. 
Uluslararası İnsan Hakları Hukukunun Bir Kaynağı Olarak Uluslararası Örf ...

67.

Organization of American States (OAS), Inter-American Convention on Forced Disappearance of Persons, 9 June 1994.

Organization of American States (OAS), Inter-American Convention on the

Prevention, Punishment and Eradication of Violence against Women ("Convention of Belem do Para"), 9 June 1994.

Organization of American States (OAS), Protocol to the American Convention on Human Rights to Abolish the Death Penalty ("Pact of San Jose"), 8 June 1990, OAS Treaty Series, Nº.73.

Özkan I, "Uluslararası Hukuk - Ulusal Hukuk İlişkileri", 2013, 8(Özel), Journal of Yaşar University s. 2127-2176.

Paust J J, "The Complex Nature, Sources and Evidences of Customary Human Rights", 1995, 25, Georgia Journal of International and Comparative Law, s. 147-164.

Pease KK/Forsythe DP, "Human Rights, Humanitarian Intervention, and World Politics”, 1993, 15 Human Rights Quarterly, s. 290-314.

Questions relating to the Obligation to Prosecute or Extradite (Belgium v. Senegal), Judgment, I.C.J. Reports 2012.

Ramina L, "TWAIL - 'Third World Approaches to International Law' and Human Rights: Some Considerations", 2018, 5(1), Revista de Investigações Constitucionais, s. 261-272.

Reisman M, "Sovereignty and Human Rights in Contemporary International Law", 1990, 84(4), American Journal of International Law, s. 866-876.

Report of the International Law Commission, Sixty- seventh session, 4 May5 June and 6 July-7 August 2015, UN Doc. A/70/10, Advance Unedited Version, 24 August 2015.

Restatement of the Law, Third, Foreign Relations Law of the United States, American Law Institute, 1987.

Risse T/Ropp S C/ Sikkink K, The Power of Human Rights: International Norms and Domestic Change, 7. Bask1, Cambridge University Press, 2007.

Robbins M, "Powerful States, Customary Law and the Erosion of Human Rights through Regional Enforcement", 2004, 35, California Western 
International Law Journal, s. 275-302.

Scharf M, "Accelerated Formation of Customary International Law", 2014, 20, ILSA Journal of International and Comparative Law, s. 305-342.

Schwelb E, "The Influence Of The Universal Declaration Of Human Rights On International And National Law", 1959, 53, Proceedings of the American Society of International Law at Its Annual Meeting (19211969), s. 217-229.

Shah J, "UDHR: Our North Star for Global Social Justice or an Imperial and Settler-Colonial Tool to Limit Our Conception of Freedom”, 2018, 31, Pace International Law Review, s. 569-576.

Shaw M N, Uluslararası Hukuk, Çev. İbrahim Kaya vd., TÜBA, 2018.

Shelton D, "International Law in Domestic Systems", in Karen B. Brown/ David V. Snyder (eds.), General Reports of the XVIIIth Congress of the International Academy of Comparative Law, Springer, 2012, s. 509-540.

Sinclair I, The Vienna Convention on the Law of treaties, 2. Bask1, Manchester University Press, 1984.

Sohn L, "Sources of International Law", 1995, 25(1), Georgia Journal of International \& Comparative Law, s. 399-406.

Söyler Y, "Barcelona Traction Davası ve Uluslararası Hukuka Etkisi", 2015, 19(3), Ankara Hacı Bayram Veli Üniversitesi Hukuk Fakültesi Dergisi, s. 207-248.

Statute of the International Court of Justice, 26 June 1945, 59 Stat. 1055, 33 U.N.T.S. 933.

Stein T, "The Approach of the Different Drummer: The Principle of the Persistent Objector in International Law", 1985, 26, Harvard International Law Journal, s. 457-482.

The Core International Human Rights Treaties, United Nations, 2014.

Thirlway H, "Human Rights in Customary Law: An Attempt to Define Some of the Issues", 2015, 28, Leiden Journal of International Law, s. 495-506.

Thirlway H, The Sources of International Law, 2. Bask1, Oxford University Press, 2019.

Trachtman J, "Persistent Objectors, Cooperation, and the Utility of Customary 
Uluslararası İnsan Hakları Hukukunun Bir Kaynağı Olarak Uluslararası Örf ...

International Law", 2010, 21, Duke Journal of Comparative \& International Law, s. 221-233.

Trimble R P, “A Revisionist View of Customary International Law”, 1986, 33, UCLA Law Review, s. 665-732.

Türe F, "İnsan Haklarının Normatif Kökeni”, 2014, 32, Sosyal Bilimler Enstitüsü Dergisi, s. 149-161.

U.N. Charter, 24 October 1945, 1 UNTS XVI., art. 2/7.

UN General Assembly, Universal Declaration of Human Rights, 10 December 1948, 217 A (III).

UN General Assembly, Vienna Declaration and Programme of Action, 12 July 1993, A/CONF.157/23.

Ünal Ş, Temel Hak ve Özgürlükler ve İnsan Hakları Hukuku, Yetkin Yayınları, 1997.

Vicuña FO, "Costumary International Law in a Global Community: Tailor Made?”, 2005, 38(148), Estudios Internacionales, s. 21-38.

Vidmar J, "Norm Conflicts and Hierarchy in International Law: Towards a Vertical International Legal System?", in Erika De Wet/Jure Vidmar (eds.), Hierarchy In International Law: The Place Of Human Rights, Oxford University Press, 2012, s. 13-41.

Weil P, “Towards Relative Normativity in International Law?", 1983, 77(3), American Journal of International Law, s. 413-442.

Weisburd A M, "The Effect of Treaties and Other Formal International Acts on the Customary Law of Human Rights", 1995, 25, Georgia Journal of International and Comparative Law, s. 99-146.

Zabunoğlu H G/Sönmez E Y, "Uluslararası İnsan Hakları Hukukunda Üçüncü Dünya Yaklaşımları”, 2021, 12(1), İnönü Üniversitesi Hukuk Fakültesi Dergisi, s. 258-270.

Ziemele I, "Customary International Law in the Case Law of the European Court of Human Rights-The Method", 2013, 12(2), The Law \& Practice of International Courts and Tribunals, s. 243-252. 